\title{
EUROPEAN INTERNATIONAL RELATIONS
}

J. A. MURRAY MACDONALD

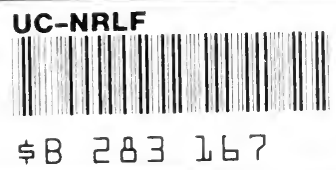



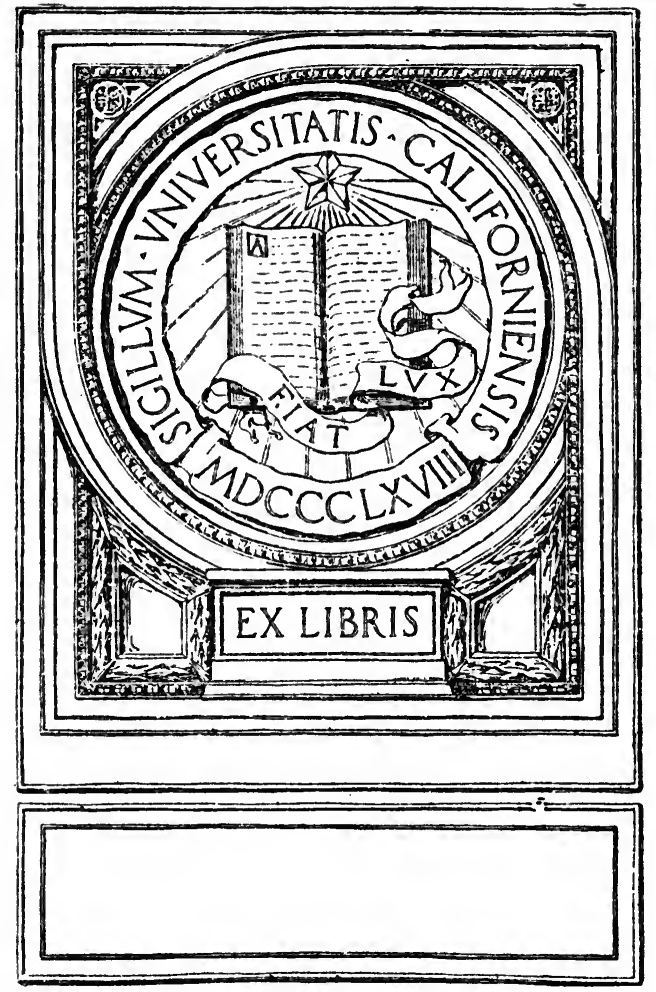
1 



\section{EUROPEAN INTERNATIONAL RELATIONS}





\section{E U R O P E A N INTERNATIONAL}

R E L A T I O N S

BY

J. A. MURRAY MACDONALD

M.P.

LONDON

T. FISHER UNWIN, LTD.

ADELPHI TERRACE, W.C. 


\section{1 $M=$}

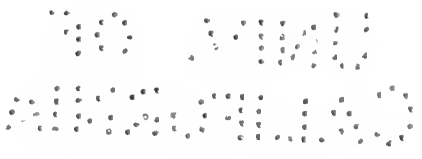

First published in 1916

(All rights reserved) 


\section{NOTE}

The first three sections of this paper originally appeared in the Contemporary Review for April 1915. I have to thank the Editor for permission to reprint them here. 
Digitized by the Internet Archive in 2007 with funding from

Microsoft Corporation 


\section{EUROPEAN INTERNATIONAL RELATIONS}

Whether as regards the number of men engaged in it, or the destructive power of the weapons employed, or the variety and extent of the interests affected by it, the war which is now being waged in Europe is greater by far than any hitherto recorded in the annals of mankind. Its immediate cause was the murder of the Archduke of Austria at Serajevo. But this crime is in itself no explanation of its origin ; and whatever may be its issues, they will not be concerned with the punishment of the deed of June the 28th. Its real cause lies deeper, and will be found, not in any single isolated event, but in a connected series of events, whose inner meaning has been revealed to us by the war itself, and by the circumstances that attended its actual outbreak. 
During the preceding twenty years all the Great:Powers of Europe had been adding, and more and more persistently as the years went by, to the strength and the cost of their armaments. Each, in turn, gave assurances to the others that, in pursuing this policy, it was acting only in the cause of peace. None had any hostile intentions towards the others. All were loyal and disinterested members of the European Commonwealth of nations ; and none had any other ambition than that its own rights and liberties, within that Commonwealth, should be safeguarded and maintained inviolate.

It was impossible that so gross and glaring a contradiction between fact and profession should not arouse suspicion among the Powers ; and, in truth, suspicion came to be the prevailing influence in European diplomacy. It was evident that a policy so burdensome in itself, so injurious to the well-being of the peoples of Europe, so opposed to the real interests of peace, could not have come into existence, and grown and spread, as this policy did, if 
EUROPEAN INTERNATIONAL RELATIONS

all the Powers had been sincere in their professions. One or more of them must have been animated by sinister aims and selfish ambitions; and a feeling began to take possession of the minds of men that, if the policy were persisted in, war must inevitably come.

It came in the closing days of July ; and with a unanimity unexampled in the history of the United Kingdom, unexampled in the history of England since the days of the Armada, the people of this country are agreed that it is Germany that was responsible for the growth of armaments, and that it is she who was false to her professions and disloyal to her neighbours. With a unanimity, moreover, unexampled in the history of the world, all the peoples of the world, not directly concerned in the war, are agreed in tracing its guilt to the same source.

This unanimity, both on our part, and on the part of neutral peoples, has been due mainly to three causes. The first relates to the circumstances which attended the outbreak of the war ; the second to the fact 
EUROPEAN INTERNATIONAL RELATIONS

that Germany was admittedly a military Power, and that she made the maintenance of her position, as the chief military Power of the world, the foremost object of all her policy; and the third to the fact that certain opinions about the rights of a State to aggrandize itself, at the cost of other States, have been widely proclaimed in Germany-opinions, the practical effects of which have frequently had illustration in the previous history of the world, but whose influence most men had fondly hoped an advancing civilization was slowly and surely undermining. I propose, as an introduction to what I have to say on European international relations, briefly to consider these points. 


\section{I}

BEFore the outbreak of the war Germany professed to be a loyal member of the European Commonwealth of nations. She professed to be bound, in common with all the other nations, by those public engagements and agreements by which their several and relative rights and liberties were defined and confirmed, and to the maintenance of which all were equally pledged.

In the face of this profession she approved of the terms of the ultimatum presented by Austria to Serbia on July 23rd, though these terms were inconsistent with the continued existence of Serbia as an independent member of the system of European States. Further, if she did not actually urge her to it, she certainly supported Austria in her refusal to submit her case against Serbia to a European 
EUROPEAN INTERNATIONAL RELATIONS

tribunal. It was impossible for the outside world to believe that she did these things in the interests of peace, and without some ulterior motive of her own.

In the face of this profession she presented to Russia the ultimatum of July 31st that precipitated the war. Up to that moment the chances of war and peace still hung in the balance. There was still at least a glimmering hope that Austria might be induced to submit her case to a European tribunal. That hope was extinguished by the action of Germany; and again it was impossible to avoid the inference that she had a purpose of her own to serve, and a purpose that could be secured only by force or its display.

In the face of this profession, moreover, she invaded Belgium, and the invasion was manifestly carried out as part of a long-prepared plan of war. Her determination to proceed in the prosecution of her objects, without regard to the rights of her neighbours, was here open and flagrant. She herself has recognized this; 
and she has tried to justify her action on the plea of an over-riding necessity that knows no law. She has used this plea to excuse also her destruction of Louvain; and to justify the "decree" of February 4th, 1915, in which she proclaimed to the world her intention to ignore all the mitigating and recognized rules and practices of naval warfare. But the plea is as morally bad as are the actions which it is used to support. When an alleged necessity springs from the nature of things, from their physical or moral constitution, then, in fact, the necessity knows no law, and submission to it knows, and ought to know, no shame. But when it is urged in support of some action which is the subject of deliberation and choice, as in all these instances it is, then it lies not in the nature of things, but in the plans and purposes of him who alleges it; and "the whining tones of commonplace beggarly rhetoric," by which it is sought to justify it, produce in honest men nothing but indignation.

All Germany's proceedings in relation to 
Belgium, her invasion of that country, the excuse made for it by her Chancellor, and the excuses made for what followed on it by her Emperor, recall the words of Milton, put into the mouth of Satan, on the occasion of another celebrated invasion, and Milton's own comment upon them :-

" "Thank him who puts me loath to this revenge On you, who wrong me not, for him who wronged.

And should I at your harmless innocence Melt, as I do, yet public reason just, Honour and Empire with revenge enlarg'd, By conquering this new world, compels me now, To do what else, though damn'd, I should abhor.' So spake the fiend, and with necessity, The tyrant's plea, excus'd his devilish deeds." 


\section{II}

These are some at least of the reasons why the world is unanimous in its judgment that Germany is answerable for the outbreak of the war. But added to them is the fact that she was essentially a militant Power. To understand this it is necessary to look for a moment at the three great fundamental establishments of the Constitution of the Empire, namely, the Legislature, the Executive, and the Army.

The Legislature consists of the Emperor; of the Bundesrath, a body of fifty-eight members, appointed by the Governments of the individual States constituting the Empire, the members acting, in all matters brought before them, on definite and detailed instructions from the Governments appointing them ; and of the Reichstag, a body of 397 members, elected by 
EUROPEAN INTERNATIONAL RELATIONS

universal suffrage and by ballot. All measures of general legislation, and all finance measures, must receive the assent of these three powers before they become operative. There is nothing here that calls for special notice. So far as it goes, the Legislature, both in function and constitution, is in accordance with the forms of a free government.

When, however, we look at the Executive, it is another aspect of affairs that presents itself. It is not the Executive of a free people that we see; but an Executive which, for all the most material purposes of the State, has no dependence upon the deliberations and decisions of the Legislature, but is absolutely irresponsible and uncontrolled. By the constitution of the Empire its whole executory system is left to be disposed agreeably to the will of the Emperor. At his pleasure, without regard to the opinion prevailing in the Reichstag, or in the Bundesrath, the great officers of State are appointed and dismissed. Both in form and in reality they are his servants and 
EUROPEAN INTERNATIONAL RELATIONS

subject to his will. $\mathrm{He}$ has in his hands the appointment and dismissal of the officers of the army and the navy; and men of all ranks, in both services, are bound by oath unconditionally to obey his orders. In case of threatened disturbance of civil order, of which he is the sole judge, he has the uncontrolled power of declaring any country or district within the Empire in a state of siege. $\mathrm{He}$ is vested with the sole control of foreign affairs. He has the uncontrolled power of making defensive war, and of determining whether the war is, or is not, defensive. And, finally, he has the uncontrolled power of bringing a war to a close, and of deciding upon what terms and conditions it is to be closed.

It is not till we look at it in its relation to an Executive power such as this that the part which the Legislature plays, in the life of the Empire, stands revealed. Its share in the Executive power of the State being merely nominal, its deliberations regarding its exercise can serve no other purpose but to screen from the people the completely irresponsible nature of that 
power. These deliberations, moreover, as they are mainly academical in their character, and can have no practical outcome in the control of the Executive power, must tend to weaken and corrupt the spirit both of the Reichstag and the people, and train it to a blind obedience to the will of the Emperor.

It is the Emperor who governs Germany ; and that the people of that country should for so long have quietly submitted to his rule testifies to their political backwardness. But it would be unfair to them not to recognize that it is a testimony also to the moderation with which their sovereigns have, on the whole, used their power in domestic affairs. Moderate, however, as these men may have been, they could not escape the ordinary limitations and weaknesses which Providence has indiscriminately imposed upon every member of our race. They may honestly have desired to exercise their power upon public principles and national grounds; but unless the law secures this exercise by subjecting it to the regulated control of a free people, 
EUROPEAN INTERNATIONAL RELATIONS

the interests of the State, both internal and external, must be, to a dangerous extent, subject to the likings or prejudices, the intrigues or policies, of the Court; and these influences have never been favourable to popular rights, or to the cause of peace.

As to the army, it is levied by conscription; and the Germans pride themselves on their willing acceptance of this principle as at once an evidence and a measure of their love of their country. If the normal relations between States imply "a war of all against all"; if the main interests in the life of a State are concerned with its external relations, and can be furthered only at the cost of its neighbours; if the source and spring of energy in its life can be fed only by the subjection to it of the life of those neighbours: then we may allow that the willing acceptance by a people of the principle of conscription, as a means of raising its army, can justly be regarded as the Germans regard it. But if, on the other hand, the animating principle of a State neither implies nor 
involves hostility to its neighbours; if its subjects believe that Providence has placed within the compass of their own domestic conditions the source and spring of all that is good in life, and the means of realizing it; if they seek to strengthen and develop their life in accordance with principles of universal equity and justice; if they believe that there is such a thing as a civilization of mankind, in accordance with which the relations of States are some day to be determined, not by force, but by an advancing opinion, regulated and guided by principles of action common to them all, then a readiness to accept the principle of a conscript army may not only not be an evidence of a love of country, but an evidence rather of a complete and utter misconception of what are its true and permanent interests.

It is to be noticed, moreover, that it is not a reasonable fear of the hostile designs of its neighbours that has induced Germany to consent to the training of its whole adult male population in the art of war. If it had been, then its acceptance of conscription 


\section{EUROPEAN INTERNATIONAL RELATIONS}

would have been, not a willing, but an enforced and reluctant acceptance; and any occasion that might have offered itself to reduce the burden of armaments, by an understanding with its neighbours, would have been eagerly seized. Such an occasion has oftener than once presented itself; but it has been invariably rejected, and rejected with contumely, as a sign of the weakness of those who made it, and as an artful device to put a stay, by indirect methods, to the growing greatness and influence of Germany.

It has been the fashion also among a class of men, very numerous in Germany, and not unknown among ourselves, to belaud war for its own sake; to maintain that it is in war only that the so-called military virtues are called forth ; and that, if wars ceased, the civilization of the world would be retarded and its spirit impoverished. Whether, in the long intervals of peace, barracks and drill yards are good schools of manly virtue, may be open to question; but it is not open to question that, in the short intervals of war, great 
virtues are displayed by men of all ranks in the field of battle. Nor is it open to question that every generous feeling, in the breast of him who is not corrupted and debased by false and shallow theories, revolts from the idea that it is only when he is engaged in the slaughter of his fellowmen, however sacred the cause may be, that these virtues can be evoked. Not to feel this would be to make of these virtues bloody idols which call periodically for the slaughter of fathers, and sons, and brothers ; for the sacrifice of all the private affections of life, and of all the virtues that spring from them.

I have somewhere read that in the battles that were fought between the captives of war in the arena at Rome for the edification of the Roman people, great valour and many virtues were constantly displayed, which, without this sacred opportunity, might never have had a chance of showing themselves. But I doubt whether, if we erected an arena in London, and there set our German captives of war to fight each other in order 
EUROPEAN INTERNATIONAL RELATIONS

to keep alive in them the spirit of valour and virtue generated on the battlefields of France and Belgium, so that, after the war, we might send them back, or so many of them as survived the ordeal, to their own country, in possession of the same fulness of virtue as when we took them captive-I doubt whether the Germans would regard our action as contributing to the sum total of their spiritual wealth; or whether the world generally would accept our assurances that we were acting in the interests of civilization. 


\section{III}

The Germans have rested their claim of right to use their army to aggrandize themselves at the cost of their neighbours on the ground that between power and right there is no real or fundamental opposition. They have maintained that, in the history of the world, power, when it has been successfully exerted, has always and everywhere been the source and given the measure of all the real and recognized rights of men. How else, it is asked, can we account for the influence which Rome has had on the civilization of the world? It was not as an apostle of the rights of men that she went forth into the world of her time and subdued it to her will. She acted under the impulse of power; and her success has been accepted by the world as the measure, and the only measure, of her right. How else, 
it is further asked, except on this view of the relation of power and right, can we account for the greatness of England today? Is not that greatness due to the fact that she has conquered India, that she rules Egypt, and that she possesses rich and populous colonies of her sons scattered through the length and breadth of the world? Is it not true that she holds all these possessions, not in virtue of a vague and abstract right, but in virtue solely of her power? And if that power were destroyed by some rival power, would not all the rights that flowed from it also be destroyed, and be replaced by rights sanctioned and enforced by the conquering power? Would not these rights, moreover, in their turn, find as general and willing an acceptance from the world at large? Has not Prussia, also, advanced to a foremost position among the nations of the world solely because of the power embodied in her army? It has been her army that has added, time after time, to the extent of her territory, and to the numbers of the 


\section{EUROPEAN INTERNATIONAL RELATIONS}

people subject to her rule; and it was her army that was the instrument by which the great German Empire itself, of which she is the heart and soul, has come into existence. In view of all this, in view of the plain and manifest teaching of history, is Germany now to be denied the right of testing her power to rule and influence the world by the only test by which that right has hitherto been measured by mankind-the test of her power to conquer? Is her life to be throttled; is her economic expansion to be hindered; is the spirit of her culture to be cabined, cribbed, and confined within the narrow limits of her present rule, at the bidding of a claim of right advanced by those who either weakly shrink from testing its validity by their power to maintain it, or who are manifestly incapable of submitting themselves to this test? To accept this doctrine would be for Germans to reject the counsel of God against themselves and against the world. Power, and the living energy from which power springs, is given by God Almighty to be used for 
the only purpose for which it can be usedthe subjection to it of the weaker peoples of the world. This is the divine plan for the advancement of the world, as has been shown over and over again by the fact that the conquered peoples always come to realize, as they begin to feel the stirrings in them of a new life, the inestimable gift of their conquerors, that their subjection was a blessing in disguise.

I will not say, in answer to an argument of this kind, that conquest has never been the means of furthering civilization; or that the conquered peoples have never derived from their subjection new and better conditions of life, and even a new and better way of living. This has often been the case. But I do say that it has never been the fruit of a systematic policy of aggrandizement, of a policy systematically pursued by a country for the sake of adding to its population, or its wealth, or for the sake of empire, or even for the extension of its influence in the world. These things, if they come to a country, come to it because it bears in its life, and carries 
with it in its conduct, something that makes a deeper appeal to the nature of man than the appeal of force, and something that can be neither estimated nor measured in terms of force. Of nations, as of individuals, it is true that they must first seek the Kingdom of Heaven before these things can be added unto them; and the Kingdom of Heaven will not be taken by force.

The plea that "might is right" is the inference which men of shallow understanding have drawn from the incontestable fact that in the history of States there is always a tendency for political supremacy to gravitate towards the side of force. It is among the weaknesses of human nature that it should be so. The Government of a State must have force at its back; and in the case of a dispute, either between it and its own subjects, or between it and the Government of another State, it is always tempted to settle the dispute in its own favour, not by a patient weighing of its merits, but by a reliance on the force which is under 28 
its control. When it yields to the temptation, as it too often does, and when it is successful in making its arbitrary will the rule of its conduct, as it too often is, then political supremacy and force become identified. But when, freed from the prejudices and passions that influenced it, we look back on the history of a State and consider whether its Government was good or bad, it is not primarily its function as an instrument of force that concerns us, but its function as an instrument of justice; and justice, from whatever other source we may derive it, does certainly not spring from force.

As to the historical examples by which Germans have sought to fortify themselves in their view that the greatness of a State and its influence in the world are measured by the extent of its conquests ; it is true that Rome, particularly under the later Republic and the Empire, used her armies to acquire sovereignty for the sake of sovereignty ; and that throughout her history her relations to other nations were those of force and force alone. It is true 
that her history exhibits to the world, as the history of no other State does, the cold abstraction of sovereignty and power, the pure egotism of the will in opposition to others, involving no moral consideration of any kind; and to this extent, no doubt, she provides a model for German aspirations and ambitions. But even on this aspect of her history it is possible to say something for Rome that it may not be possible to say for Germany. For, whatever may be the sanction which lies behind the claim of national independence, that claim has acquired a respect in our time which no one ever dreamt of conceding to it in the time of Rome. 'There is a public law of Europe, imperfect as it is both in substance and sanction, which implies a community of European States, feeble as the sense of it may be, a community which, in its turn, implies an acknowledgment of the claims of national independence, irrespective of the physical power to maintain them. A State which openly breaks this law, and openly violates the principle of community, of which the law is the outward expression, 
may at any rate be accused of a transgression which cannot justly be charged against Rome.

But beyond this, it is false to say that the greatness of Rome is measured, or is measurable, by the extent of her conquests. It was not her military organization, nor what was effected by its means, that put the world in debt to Rome. These were perishable things, and they are dead. What made Rome, what gives to her life an imperishable interest for mankind, was her internal history, her slow working out of that struggle between Patricians and Plebeians from which there finally emerged the full and complete recognition of a principle of right not dependent upon national or individual disposition or sentiment, but equally applicable to all men in all countries and in all times. It was the spirit which guided this struggle that was the source of all her greatness; and it was the legal system, in which it found its highest expression, which influenced, and will always influence, the life of men. As to England, the secret and the source of 
her greatness and influence are to be found, also, as in the case of Rome, in the spirit of her people, and in what they have made of their life at home. She has never been a military Power. Taking our history as a whole, no great European State has ever given less time or thought to its army and its equipment. We were a great Power before we ever had a regular army. It is true that for long we have had the most powerful navy of the world. But if conquest had been the object and purpose of our life, the navy would always have held a position subordinate in importance and function to the army. For a scheme of conquest calls, first of all, for war on land ; and in such a scheme the part that a navy would be called upon to play would be that merely of an auxiliary to the army. On the other hand, in the case of an island Power, such as ours is, intent chiefly on defending its own liberty and independence against aggression from others, the relative importance of the two forces becomes at once reversed. The navy then becomes the prime interest, and the army assumes 
the role of an auxiliary to it; and both are merely instrumental to a purpose that lies altogether outside the scope of their operations.

If we were asked what we thought was the source of our influence in the world, there is not one of us, whether he be soldier or sailor or civilian, who would answer that it has been our army or our navy, great as have been the services which they have rendered to us in the course of our history. That history has been, beyond and above everything else, the history of an internal struggle for liberty. It was the conduct of that struggle that made England what she is. It is its results that make her to-day a great influence and a great power in the world. Nor is it without bearing on the German contention to add that we have never regarded the possession of liberty by other peoples with an envious or a grudging spirit. On the contrary, we have always used our influence, and not seldom our power, in support of those who were struggling for freedom, or who were engaged in defending it against the attack 
of powerful neighbours. We have been accused, indeed, of doing this on sinister motives and for indirect ends of our own, but only by those who neither understood our spirit nor had any sympathy with it.

As to Prussia, it is her own case that her greatness and influence depend on the strength of the army by which they are backed; and, justly enough, she points to her own history in support of this case. She has had no internal history from which have emerged great principles affecting the conduct of the life of men. As a State she has contributed nothing to the well-being of the world. She has been from her first beginnings an aggressive Power; and what she has been she remains to this day. In the most minute part of her internal arrangements she has had war in view; and she has made war, not to make her neighbours more observant of right, but to make her their mistress. To be the neighbour of such a State is to live under the continual dread of immeasurable evils; "its influence is equal 
to a war, its example more wasting than a hostile irruption."

"This state of things cannot exist ... without involving all the surrounding Powers in one common danger, without giving them the right, without imposing it upon them as a duty, to stop the progress of an evil ... which attacks the fundamental principles by which mankind is united in the bonds of civil society." This is an extract from the Whitehall Declaration of October 29, 1793; and it applies to the state of things to-day with at least as much force as it did to the state of things then. The fundamental principles by which mankind is united in the bonds of civil society are in as great danger now as then. Germany must be resisted, and the resistance must be continued, till her spirit has been so sobered and subdued as to give ground for the hope that she may be willing to become, what she has never hitherto been, a loyal member of the community of European States. 


\section{IV}

$W_{E}$ are in the midst of a war from which Europe cannot emerge, again to take up the lines of her life just where she dropped them, as she entered into it. The war, as we have seen, was begun by Germany in pursuit of aims and ambitions of her own. Her first act in it was to make a breach in those international engagements upon which the community of Europe, such as it was, actually rested. She has carried it on, both by land and by sea, with a total disregard of those usages and conventions by which the civilized world had sought to mitigate the horrors and miseries that must, in any circumstances, accompany a state of war. By her conduct she has made a schism, between herself and the whole world, more complete than has ever been made by any people in the recorded history of mankind. It would be wrong, 
however, to attribute this simply to what she has done. Other countries have, in past times, done things of the same kind without incurring the same universal reprobation. It is not Germany's ambitions, nor her policy of "frightfulness," that are new in the history of the world, but the universality of the condemnation they have evoked. It is as if this war had awakened in the peoples of the world a new conscience about the sanctity of that public law and those public engagements, by which nations have been feebly and uncertainly seeking to realize and cement their common aims and interests as members of the great human family.

The old doctrine, that wars are suits to the tribunal of God's justice, that they are to the community of nations what the ordinary means of justice are to single societies, and that nothing can banish them from the world that does not also banish international justice from it, begins to have for us a more doubtful authority than it had for our fathers. We begin to find it increasingly difficult to believe that God's 


\section{EUROPEAN INTERNATIONAL RELATIONS}

judgment on the merits of a dispute between nations is necessarily made manifest to them only by a trial of their relative power to destroy each other. When we look back on the history of the world, it would be foolish to deny that war has often been the means of securing justice. But it would be equally foolish to deny that it has at least as often broken out and ended in total disregard of any principle of justice, divine or human.

No one fighting against Germany can believe that her victory in this war would be the expression of God's judgment as to the justice of her cause. We should all, with one mind and will, revolt against it, and at once begin to prepare ourselves to secure its reversal. Will Germany be animated by the same spirit in case of her defeat? 'This is the question which, as the war approaches its conclusion, will loom larger and larger on Europe's horizon. Germany has threatened that, in case of her victory, she will so rearrange the map of Europe, and so crush and cripple her enemies, as to make it difficult or 
impossible for them again to rise against her. That way war inevitably lies. We have not threatened her in the same way. That is not the spirit in which we entered into the war; nor is it the spirit in which we look forward to the future. Germany's downfall will not by itself add to our strength, nor help us to repair our broken life. It was not to work her ruin that we intervened in the war; nor is it her ruin that is for us its necessary end. The great issue that is now being fought out on the battlefields of Europe, the issue by which the meaning and importance of the war, for the future of our race, will ultimately be tested and measured, is the binding character of international engagements, and of these as the means of securing the freedom and independence of nations. To a recognition of this Germany must be brought. She must be forced to recognize that these engagements are not mere scraps of paper, to be torn up at the arbitrary will of those who enter into them. She must be taught that her own freedom and independence rest on the same sanction as the freedom 
and independence of her weaker neighbours; and till she has learned this lesson the war must go on.

But it is a lesson which the war is bringing home, not to Germany alone, but to all the nations of Europe. Hitherto, each of them has been too ready to assume that its freedom and independence rested on its own isolated power of maintaining its life against the others; and its relations with them have been too largely regulated by this assumption. Each has assumed that it had within itself all the means necessary to a completely selfsufficing life; or that, if it had not, it had an inherent right, without regard to other nations or their interests, to adopt such measures as might seem to it expedient to secure these means. To satisfy the material wants of its life, and to protect it from dependence on other nations, it claimed a right to exclude from its markets the products of their industry and agriculture; while, at the same time, if it had more of these products than its own people could consume, it claimed a right 
to enter, and if necessary to force its way into, the markets of other countries. If it had an overflowing population, it looked with jealousy on the migration of its surplus to the more sparsely populated territories of its neighbours. This seemed to be an unnatural and improper aggrandizement of their life at its cost; and to be prevented, therefore, by the seizure of their territory whenever an opportunity for doing this presented itself. There has even been a tendency of late years to carry this view of the meaning of the freedom and independence of nations into the sphere of intellect and morals, as if within it, also, to be dependent on others was a reflection on the spontaneous virility of a nation's own life.

This has been the too prevalent theory of the meaning of freedom and independence entertained by the nations of Europe; and unless this war helps to rescue them from it, it will have been fought largely in vain. If it is a true theory, then the binding force of the engagements which nations enter into with each other must always be 
weaker than the alleged necessities of the life of any one of them ; and wars between them must always be inevitable. For the theory makes the naked, isolated arbitrary will of every nation the sole law of its conduct as to the concerns of other nations ; and it sanctions the idea that each nation is entitled to wage war in order to bring other nations, and all that they have or possess, into subjection to it. To say of the theory that it rests upon and that it nourishes, not the common humanity of the nations, but their isolated self-will and their desire for self-aggrandizement, is to say of it what is no doubt true, but what does not give us any principle efficacious for its correction. For humanity, as we know it in its practical working and development, is identical with the separation of mankind into distinct nations. In Europe, pre-eminently, this has been the slow and not yet completely accomplished result of the whole movement of history; and if history is to be our guide in moulding our common humanity, it is from this movement and its interpretation 
that we must obtain our leading and constructive principles.

Side by side with it and as an essential part of it, there has been a movement of precisely the same character, affecting individuals, within each nation. It was, in fact, the claim of individuals to be freed from the control of arbitrary will and despotic power that gave to the movement towards the separation of the peoples from each other its whole meaning and significance. When, moreover, this separation had once been effected, the internal domestic history of each nation has hinged, more and more clearly as time has elapsed, on the claim of its individuals to be free, equal, and independent members of it. It is this claim that has been the spring of all the movements in the domestic life of the several nations, the motive of every change that has taken place in their internal organization. There is no State in Europe which has been able to evade it; and there is none which has not, to some extent, recognized its validity, and which has not, also, succeeded, more 
EUROPEAN INTERNATIONAL RELATIONS

or less imperfectly, in reconciling it with the conduct of a life common to all its subjects.

The actual historical connection between the claim of individuals to their freedom and independence with the claims of nations to theirs, suggests the question as to whether the two claims do not spring from the same source and ultimately depend for their efficacy on the same sanctions. It may repay us to consider this; and, in the first instance, to look at the source and sanction of the individual claim. 
In their dealings with the subject, all the writers who have had a large influence in forming opinion upon it, both in this country and on the Continent, from Hobbes and Locke to Rousseau, Mill, and Bentham, have started with an assumption about individual freedom entirely analogous to the assumption we have been considering about national freedom. But there was a material difference between the two cases. As a matter of historical fact, nations have come into existence and have developed themselves into States by asserting and maintaining their own freedom against, and their independence of, any superior earthly authority. They have regarded their freedom and independence as being already complete; and have held that to subject it to any authority common to them all would be to derogate from it in the case of each. 
In the same way, but without any historical justification, these writers all start with the idea that the individual comes into existence in possession of his freedom. Man, they say, is born free. It is his freedom that alone distinguishes him from the lower animals. In virtue, therefore, simply of his humanity, every man has a natural and inalienable right to the unrestricted and unhindered exercise of all his powers.

This was the proposition from which they all in common started. I am not here concerned with the fact that their assertion of it did undoubtedly produce a large, and, on the whole, beneficial result on the life of the peoples of Europe, that their influence was both a liberating and a vivifying influence. What, in view of our question, is of importance to note, is that after having made the assumption, they found themselves faced with the fact that the individual did not lead an isolated life, that he everywhere lived and acted as a member of a community of individuals, and, so far as they were concerned about him, as a 46 
member of a community organized as a State; and that the State did, in manifold ways, restrict his liberty of action. How, then, was the assumption to be reconciled with the fact? This was their difficulty, and no two of them met it in the same way. It was impossible that they should. For if freedom is the distinguishing characteristic of human life, and if we are each in full possession of it simply in virtue of our birth as human beings, then the restrictions imposed upon it by the State cannot possibly be reconciled with it. 'This, however, was not a conclusion which they could thus baldly accept. They could not simply propose to do away with the State and leave us all in full possession of our freedom, even though they held that this freedom was of the very essence of our life. The real facts of human life were too obvious to allow of this proposal being made; and they were, therefore, forced to resort to a variety of assumptions about the State, made for the purpose of adjusting its action to their fundamental assumption about individual freedom. The chief 
of these was that the State came into existence as a Social Contract, to which all the individuals originally constituting the community were supposed to be freely consenting parties, and in accordance with the conditions of which their individual liberty of action was to be governed and controlled. But they did not explain how, when differences as to the interpretation of the terms of the Contract arose, these differences were to be settled on the basis of free and individual consent. Hobbes, indeed, boldly stated that this was impossible, and that the interpretation and its enforcement must be left to a supreme and irresponsible governing authority. But this was too obviously inconsistent with the most elementary idea of individual freedom ever to find large acceptance. Much more popular was the idea of Bentham that it was the greatest good of the greatest number that ought to guide the action of the State in settling differences between its members. This had at least the appearance of being a sound moral principle, and it was workable. But it did not explain why the 48 
EUROPEAN INTERNATIONAL RELATIONS

good of the minority should be sacrificed to the good of the majority, except on the ground that the one was, as a mere matter of fact, a minority, and the other a majority. Nor did it explain why the good of the minority of to-day might become the good of a majority to-morrow, except again by the test of mere numbers. The State had nothing to do with these questions. It had simply to register the decrees of the majority of the day, and to use its power to force them on the minority.

In truth, behind the political theories of all these writers there lay the idea that the State was simply an embodiment of force, and that its sole function was to compel individuals to obey its commands. It was inevitable that it should be so. For, on the assumption that the rights and liberties of the individual exist independently of the State, and that they have a claim to recognition which the State does not give and cannot justly take away, then any State restriction of these rights and liberties must be imposed simply by 
the might of superior force; and no device or sophistry of reasoning can convince us that it is not so.

Either, then, the individual is not free simply in virtue of his humanity; or if he is, then the State of which he is a subject must be an instrument of power and not of freedom; and the relations between States must be determined, not by common rights derived from a common freedom, but by the power of each to force its will on the others. But if, on the other hand, we admit that both nations and individuals are, and have a right to be, free and independent, then we must have recourse to some other and truer grounds for our explanation of the origin and meaning of their respective claims.

As to the individual, it is true that every man identifies, and is right in identifying, his own freedom with his own will, and not with the will of another or any number of others. When he acts in obedience to his own will he feels himself to be, and actually is, free. When he acts simply in obedience to the will of another he neither feels, nor 
is, free. And if we care to say that his will is born with him, and that he is therefore born free, we may do so. But we can say it only in the same sense as when we say that his reason and affections are born with him. We do not mean, in this case, that he is born in the full possession of them. We mean that he is born with a faculty of reason, which is awakened in him and gradually developed by the relations and conditions of his life. So it is with the affections; and so it is with the will. No man ever thinks of himself as equally free in all he does, or in all the stages of his life, any more than he thinks of himself as equally reasonable or equally affectionate. There are two sides to his nature, or rather there are two elements or factors in his life as a man, which are in continual conflict within him. He can ignore neither without injury to both. Together they constitute the man. But they are not equal elements in the making of him as a free man. In and through the one he has to bring the other into his subjection and control; and the measure of his 
success in doing this is the measure of his freedom.

When we talk about a man's being the slave of his passions or appetites, we do not mean that he is a slave in reality, obeying something outside of himself and beyond his control. It is he, himself, who acts in accordance with the promptings of passion or the cravings of appetite. We say that he is a slave because he is subjecting his will and his life to influences and conditions which can permanently satisfy neither, and which tend to weaken and destroy both. Moreover, he himself feels and knows that this is true, even while he acts as he does. He feels and knows that it is to himself that he is in bondage. If he did not, he could never attain to freedom, for it is of its very essence that he must win it for himself by the sweat of his own spirit. It is in and through himself alone that he can become a free man.

But it is not enough to say that his freedom is a thing of slow growth, the fruit of struggle, and that he has to win 
EUROPEAN INTERNATIONAL RELATIONS

it for himself. For it is not the mere desire to be free that induces him to enter into the struggle, or that keeps it alive. What, then, is it? The answer is plain, and, so far as I know, is not disputed. It is some idea of an unattained good for himself, which is present in him as a constant impulse to seek after and follow it. It is in this idea that he finds the end and purpose of his life; and it is to realize it that it is necessary that he should be free, and free not merely from external hindrances and restrictions alien to its attainment, but free also from the equally alien influences of his own natural impulses and passions. The idea itself may not be constant. It very rarely, if ever, is. It may be one thing in one period of life, and another in another. It may be the idea of wealth, or of power, or of fame; or it may be an idea of a good which is none of these and which is not dependent on any or all of them for its attainment. But whatever it is, so long as he holds to it, it is to its attainment that the individual looks for the fulness of his 
life; and it is in the willing direction of all his powers and energies towards it that he finds his freedom. To allow himself to be tempted away from it, and to dissipate his will in other directions, is to allow himself to do what he knows he ought not to do. Moreover, when he changes his ideal, he does so only because he finds, or thinks he finds, in the new ideal a fuller satisfaction of himself and a larger freedom. Through all the changes, few or many, he remains constant as an end to himself, and he strives, more or less consistently, to control, regulate, and discipline his life in accordance with the character of the particular ideal which he sets before himself; and this selfimposed discipline is the only discipline consistent with his freedom.

But though the ideal must be his, and must be realized in his life and conduct, it neither does nor can originate in him as an isolated human being. A man completely shut up in himself, if we can suppose such a being, can have neither ideal, nor freedom, nor motived will, nor anything else that is characteristic of his humanity. He would be 
simply an animal. As a matter of fact, he is everywhere seen to live, move, and have his being as a member of a community; and it is from his relations with his fellowmembers that he derives his ideal, and always and everywhere the ideal is conditioned by these relations. As a member of a family, for example, he finds his good in and through his relations with his family. The good, moreover, is common to all the members of the family. Each finds his own good in that of the others. 'They are all members one of another. Each, further, finds that he can attain his good only through his willing co-operation with the others, as they can find theirs only in and through their willing co-operation with him. This, in essence, is what all free, conscious, corporate human life must be ; and, so far as history tells us anything about the subject, it is from this first and most primitive form of human incorporation that all the later and more complex forms of it have sprung and, in the slow process of time, developed.

These things are fundamental to any 
rational conception of the freedom of the individual. He must find the satisfaction of his own life in his own conduct of it. He must be an end to himself and not a mere means to an end that lies outside himself. Nor can he be free, unless the satisfaction of his own life involves a purposed unity and order in it. In wayward, capricious, uncertain action, in action simply in obedience to the impulses which come and go with the moment, he can neither find, nor even think that he can find, his real freedom. Unity and order may not always be freedom; but freedom, to the extent of its realization, is always unity and order. The individual, therefore, has to realize his freedom for himself in and through a constant, severe, and ever watchful struggle with feelings, desires, and impulses which belong to his nature, but which are not, in and by themselves alone, consistent with his idea of what constitutes the real, permanent satisfaction of his life, and which have, therefore, to be moulded and guided by him in conformity with this idea. Lastly, though 56 
EUROPEAN INTERNATIONAL RELATIONS

the idea which gives a purpose and a harmony to his life must be realized in and through himself, it cannot be realized by himself alone. His life is necessarily a life of relations with others. In everything he does, and in everything he thinks or feels, so far as thought or feeling affects his action, he is brought into contact with his fellows. He acts on them, and they on him, and out of the action and reaction his life and theirs is built up. If, moreover, there is any truth in the idea of progress, then this progress must make itself manifest in an enlarged conception of the individual and the common good, and in a corresponding reformation of the relations of life.

All this may be assented to; and yet it may be, and has been, objected that there are actual limits to the satisfaction of the individual, difficult to reconcile with the idea that each man is an end to himself, and difficult, therefore, to reconcile with the idea that freedom is necessary as a means to the attainment of the end.

Men, it may be said, do everywhere 
live in communities, each community having a more or less clearly defined and regulated system of relations between its own individual members. This system constitutes the life of the community. It is the relations, and the spirit which animates and preserves them, that the individual members have in common one with another. In his inner life and consciousness, in the sources and springs of action, the individual can have nothing else in common with his fellows. As a mere matter of fact, he has nothing else -neither parents, nor brothers, nor sisters, nor wife, nor children, nor anything else that is outwardly his. In the case of a community so simple and direct in its relations as the family is, it is not difficult to see how the individual may realize his life in the life of the family, how he may live in the common life, and the common life, in all its relations, in him. The two sides of his life lie, as it were, close together, and in the purpose of his own life he may embrace all the relations of the common life. But in a commu- 
nity such as a modern European community, embracing many thousands of families and many millions of individual members, involving, also, an almost infinite complexity of relations of all kinds and all degrees, it is not so easy to see how this can be done. Here the two sides of his life fall, or seem to fall, far apart. He cannot embrace, either in thought or in action, all the relations of the common life. To work out the purpose of his own life, he has to make a selection. $\mathrm{He}$ has to choose the part he has to play in the life of the whole, and to choose it with the knowledge that it is only a part. He may, indeed, realize, and consciously or unconsciously he always does realize, that the spirit which he carries into his sphere of action is the same spirit as all other members of his community carry into theirs. His freedom to choose is itself a testimony to the fact that he is a sharer in a spirit common to him and to them. For without this common spirit he could not have this freedom. None the less, 
within his limited sphere of action he cannot, and he knows that he does not, obtain complete satisfaction for his life. His spirit is wider than the actual realized relations within which it finds its expression. $\mathrm{He}$ is conscious of aspirations and of capacities that far transcend his real life, and that cannot be realized by him under the limited conditions of time given to him to live. How, then, can he be said to find his freedom in his power to satisfy his own life?

It may further be said that the relations of human life are not fixed and stationary. They are not the same in any two succeeding generations of men. They are being continually modified by increasing communications between members of the same community and between them and members of other communities. New wants present themselves, new fields of endeavour are opened out, new relations are established, the life of the community enlarges and expands itself; and with every enlargement and expansion some change takes place in the life and the relations of its 60 
individual members. We say of this movement that it is progressive, and progressive towards a better and more complete life. But what this better and more complete life in its fulness is we do not know. What we do know about it is that we, in our day and generation, are not in possession of it; and that, if it is ever to be reached in a life lived under conditions of time, its enjoyment must be reserved for some generation of men, living in an indefinitely remote future, whose good fortune it will be to enter into the possession of the inheritance of all the ages. In the meantime, it would seem as if we were mere means towards its accomplishment, sacrifices on the altar of a life that we know will not be ours. How then, it may again be asked, can the individual find the satisfaction of his own life in the idea of an end which he is free to work out for himself, when it is admitted that the character and conditions of this end are determined for him by a life of which he is only a partial sharer, and whose end continually recedes in time as he advances 
towards it? Is it not, rather, true to say that his individual life is lost in the life of his community?

These two objections to our acceptance of the idea that the individual is an end to himself are only different aspects of the problem that always presents itself to us as often as we contemplate what Burke calls "the mysterious incorporation of the human race"; and we may treat them as one.

No one, in our day, disputes that there is a progress in our life, both individual and common. It is this that makes our life. No one disputes, moreover, that he was born into a community, with the making of which he had nothing to do, and that after he is dead the life of the community will still go on. He no more disputes this than he disputes the fact that the oak lives and grows through the annual shooting and falling of its leaves. None the less, no one ever really thinks of his life, and its relations to his community, as being like that of the leaf in relation to the tree. If he used the 
metaphor at all, he would say, and say truly, that he was in his own life both leaf and tree. Leaf and tree have each a visible outward existence. But this is not true of individual and community. The English community, for example, does not exist in its Parliament; nor in the volumes of its laws; nor in the hierarchy of officials by which those laws are administered; nor in its fields or factories. These are all merely instrumental to the maintenance and furtherance of the common life. The community exists in its individual members, in them and nowhere else either in heaven or on earth. It is in their life and their individual consciousness of its meaning that the community finds its life and the consciousness of its meaning.

A man's life, it cannot be too often repeated, is a life which he can work out, whose meaning and purpose he can understand, only in and through relations with his fellows; as they can work out and understand the meaning and purpose of their life only in and through relations 
with him. The relationship is common and co-operative; and, though it embodies itself in the outward circumstances of life, it is not itself seen or seeable. It is not the outward circumstances in themselves. Its source and spring, its animating principle, lies in the consciousness of it in each one of us. Its working out is in common: its conscious realization is individual. It is my conscious personality and your conscious personality that are being realized in and through it; and not some third personality to the making of which we contribute ours; and the idea that the community, or the State, has a life or a purpose of its own, independent of the life and purpose of its individual members, is either the fiction of arbitrary and despotic power or it is the chimera of an empty imagination. A full and complete conscious individual personality is the object of all human endeavour. The end is the same for all, otherwise there could be no co-operation in its attainment; nor could there be this co-operation unless the living, active spirit that impels each one of us to 
seek after the end was also the same in all.

Our progress towards it is slow and gradual. We have to win our way to it by a struggle, carried on in each one of us against selfish impulses and passions, which we have to subdue to it. It may be true, and it is true, that a final victory in this struggle, that the fulness and completeness of his life, can never be won by the individual within the limits of time allowed to him in his life on this earth. But it is equally true that it cannot be won by the community. Let us cast our thought into the future as far as we will, let us enlarge the common life till it embraces all mankind, and it will still be true that the life of the community is what the life of its individual members is.

What is true about human progress, in this aspect of it, is that the area of relations within which the individual is free to realize his life is gradually expanding; and that this expansion runs through the life of mankind as a whole. But what is also true is that there is in each stage the promise of a full and complete life; that this promise gives the impulse towards the attainment 
of every subsequent stage; and that the promise is given not to the community as such, nor to mankind simply as a totality, but to the individual as a member of his community and of his race. How otherwise could it be the growth and expansion of a conscious, self-realizing life?

Before passing from the subject of individual freedom, there is still one further point which has to be considered. We have seen that the individual everywhere lives as a member of a community; that his freedom within his community implies that he must be an end to himself, but that the end can be realized by him only through co-operation with his fellows; that this corporate and co-operative realization in its turn implies that the end must be the same for every member of the community; and we have seen that the end never can be completely realized either by individual or community within the limits of time. But if these things are true, as surely they are, then the end must find some definite expression in the life of the community. Where are we to look for 66 
it? To this I answer that it is to be found in the religion of the community, in it and in it alone.

It is a commonplace of historians that nothing divides communities of men so fundamentally and so completely as differences of religion; and that nothing unites them so closely in the bonds of trust and confidence as the possession of the same religious beliefs. It is in their religion that men reveal the inmost meaning of their life. It is from their religion that they derive all the final sanctions of their moral duties to each other. It is by its spirit that they guide their relations with each other; and it is in accordance with its inward impelling influences that they gradually mould these relations into a nearer and nearer approximation to its ideals.

It is in the religion of Christ that we find the key to the interpretation of European civilization, and of every civilization that preceded it, and out of which, in the fulness of time, the revelation of it came. When Christ said that we 
were His brothers, and sharers with Him in the life of God, $\mathrm{He}$ did not mean that our relationship to Him, or with Him to the common Father of us all, was a relationship of the flesh, springing from our animal existence. That existence we share with the lower animals. What we share with Christ in God is not something merely temporary and perishable, the life of a day. Christ became flesh to reveal to us spirit; and spirit not simply as a local possession, something that was to be seen in the burning bush, or in the clouds of Olympus, or in the vault of heaven; nor as merely national; nor as belonging to one man and denied to all others; nor as belonging peculiarly to one class of men; but as belonging alike to all, to Jew and to Gentile, to Greek and to Barbarian, to sovereign and to subject, to bond and to free. It was a revelation to man's spirit of its own potentially universal, divine, and eternal nature; and through it man's spirit became potentially free.

But there was also more than this in His revelation. $\mathrm{He}$ revealed to us the 68 
perfect life in God. What this life is, in its fulness and completeness, we can as little tell as we could when we considered it as the possible end of an indefinitely extended progress of the race on this earth. But the fact that it exists as a present reality in the divine life, and as a promise in our life, God's Spirit bearing witness of itself in our spirit, and that it is our duty as children of God to bring our wills into accordance with it, is the only true source and spring of progress in the life and relations of men. It is, moreover, not a life that is merely laid up for us in heaven, as the Churches have been too ready to tell us. We are already partakers of it. To it the lusts of the flesh, the desire for wealth, or for personal aggrandizement in any of the forms it may take, have to be brought into subjection. To the extent of our power we have to realize it in the day-to-day relations of our life here on this earth. "Thy kingdom come, Thy will be done on earth as it is in heaven," is a prayer which embodies the very essence of Christ's moral message to man. 
If we try to apply this prayer, and what it involves, to some of the political problems which have presented themselves in the history of modern Europe, and particularly to the claims of individual right which have everywhere asserted themselves, we should say that the appeal of Christ is primarily an appeal to the individual. The Christian religion consecrates the life of the individual as no other religion has ever done, or has ever attempted to do. It is in accordance with its innermost spirit that it gives to him rights, against which no earthly power can have any just countervailing rights, rights not merely to the full and free enjoyment of his spiritual life, but to the outward conditions of life which make this enjoyment possible. Without these conditions the rights are formal and the life unreal. These rights, however, are only one aspect of the practical bearing of his religion on his life. It is of the essence of this religion that the individual can claim rights only on condition that he fulfils in spirit and in truth the duties that answer to them. He has from hour to hour and 
day to day to earn his rights by the willing performance of his duties. It is the doing of the duty that sanctions the claim of the right.

It follows that while the appeal of Christianity is primarily to the individual, it is made to him as the member of a society. For just as, in the relations of our life, the claims of right have an individual reference, so the obligations of duty have a social reference. He who lives to himself alone cannot be a Christian. As a follower of Christ he can find his life only in a living, active, and willing co-operation with his fellows, as they can find theirs only in a living, active, and willing co-operation with him. All must be members one of another. $\mathrm{He}$, therefore, who, in a Christian society, claims rights, and seeks to enforce them, without regard to his duties, is false to his religion, and, whatever may be his position in life, sovereign or subject, master or workman, he acts in the spirit of the despot. On the other hand, to be made the subject of duties, and to have no rights corresponding to them, is to be a slave. Willingly, 
with my whole being, reason, passion, and affection consenting and co-operating, to recognize that my rights are sanctioned by the same spirit that sanctions the rights of my fellows, and that calls upon me to fulfil my duties towards them with the same authority as it calls upon them to fulfil theirs towards me, is to be a free man. It is in society, and in the secular relations of society, in them and in them alone, that we can realize and make manifest the meaning of the life revealed through Christ as existing in each one of us.

What other interpretation than this can give an adequate explanation of the great outstanding facts of our life? What other interpretation can account for those claims of individual right which ignore all distinctions of station and fortune, in accordance with which all men are equal in the sight of God and in the eye of the law, and at the same time account for those obligations of duty which control and regulate the claims of right? How else can we give a rational account of the dis- 
tinctive character of European civilization? From what other source can we obtain a clear and intelligible grasp of the differences that distinguish the life of the peoples of Asia from that of the peoples of Europe? Where else can we get an understanding of the differences between the governing principles and sanctions of the modern State and the States of Greece and Rome? How else can we explain the consciousness of his own freedom on the part of the subject while acting in obedience to the control of the State, unless the principle of this control springs from the same inner source and has the same spiritual sanction as the principle by which the subject controls and disciplines his own life? How else can we account for the progressive character both of individual and of social life unless the principle that guides and moulds them derives its authority from a source superior to both, and which it is the object of both to bring into fuller and fuller manifestation, each in the process supporting and being supported by the other? By what other interpretation of the facts of 
EUROPEAN INTERNATIONAL RELATIONS

our life can we with certainty relegate force to its proper and subordinate position as an instrument for the protection of a life which derives all its real power and all its real sanctions from its own spirit? How else, finally, can we put a just limit to that spirit of aggrandizement which, on any other interpretation of our life, so easily masters and moulds the individual and society to itself? 
Is the light of this theory of the meaning of individual freedom and independence, let us now turn to consider more closely freedom and independence as characteristic of separate nationalities. The subject presents two aspects. The first relates to the origin and meaning of the differences between nations; and the second to the State as the embodiment of the supreme sovereign power of the nation.

National differences have generally been identified with differences of race; and it has been assumed that just as, in the world of animal life, one species is marked off from others by the possession of peculiar and specific characteristics of its own, in accordance with which it comes into existence and lives and dies; just so has it been, and must always continue to be, with nations. Each has its own natural 
characteristics, in accordance with which it must regulate both the domestic relations of its life and its relations with other nations.

That there has been much in the actual history of mankind to justify this assumption is not open to question; and the further we go back in that history, the less questionable it becomes. It was largely true of the nations of the ancient world. Of these, the Jewish nation may be taken as generally typical. 'The Jews were, in their own eyes, a race by themselves, possessing a religion peculiar to them, a religion which inhered in them in virtue of their race, and which no other race could enjoy; and with race and religion together they identified their nationality. With some modifications, the same may be said to be true of the Greeks ; and, with still larger modifications, of the Romans. But it is not true of the nations of our world. 'There is not a nation in Europe that does not contain within it a mixture of races. In the United Kingdom, Celt and Anglo-Saxon 76 
EUROPEAN INTERNATIONAL RELATIONS

and Dane and Norman, in spite of their differences of race and descent, have all combined in the working out of a common national life; and as it has been in our case, so it has been in the case of other nations. Difference in race is not, in the modern world, the ground of difference in nationality. Nor is it difference in religion. We vary from each other in some of its ceremonies, and in some of its subordinate doctrines; but in the fundamentals of our religion we are all in agreement. Nor do the nations of Europe differ from each other in the principles of their civil polity. These have all been derived from the same sources; and they have all been digested into system and extended and liberalized under the same general influences. Nor, finally, are the differences to be found in manners, customs, or systems of education. These-religion, law, manners, customs, education-are at bottom the same in all; and in respect of them, the essential things of our life, Europe is virtually one great commonwealth of nations. It is not, therefore, in them that we have to seek for 
EUROPEAN INTERNATIONAL RELATIONS

those differences which justify the claim that each nation makes for the freedom and independence of its own life against the others.

Where, then, are they to be found? Partly, I think, in differences of language. For there can be no close, intimate community of life where there is no community of speech ; and race differences are important in marking off one nation from another mainly, if not entirely, because they are accompanied by differences of language. But beyond this there is the fact that no two of the nations of Europe have had the same history. They have come into existence at different times; they have reached different stages in their development; and in no two of them has the development been of precisely the same kind. In working out the principles underlying the life of all, partly because of these differences in time of origin, partly also because of differences in external surroundings and internal conditions, each has developed characteristics of its own, with which it identifies its life, and which do $7^{8}$ 
in reality mark it off from the life of the others. No continental nation, for example, though working on the same foundations, could have erected on them the same superstructure of life as we have built up in these islands. Nor could we have made of our life what the land-locked peoples of Central Europe have made of theirs. External surroundings and internal conditions were too diverse. But each claims respect and recognition for what it has made of its own life.

More important, however, than difference of surroundings and conditions is the difference in the stage of development attained by the several nations. We have seen that the individual realizes his life, and learns to know what it means, in and through his relations with his fellows; and that his freedom within those relations implies the possession of rights to the exercise of his capacities, so far as this exercise is made by him consistent with the ordered unity of the relations of the whole community of which he is a member. His regulated freedom and the rights which it 
involves rest upon and are determined by the possession of the same regulated freedom and the same rights by every other member of his community. What they owe to him in virtue of his freedom, he owes to them in virtue of theirs; and it is this reciprocal obligation that sanctions the freedom. It is, in other words, sanctioned by our morality, as determined by a common individual and inward spiritual conception of the end. and purpose of our life. But we are not always equally moral. In pursuit of selfish purposes of our own, we constantly transgress the rights of others, as they do ours. We cannot, then, depend simply on moral disposition to secure us in our rights. Nor can we depend on our own unaided individual efforts. If we had to do so neither morality nor the religion that sanctions it could ever in fact have come into existence. For by nature we are very unequally endowed as regards both bodily and mental powers; and these differences would every day make themselves felt either through conflicts of brute violence 
or artful cunning. From these conflicts, and the chaotic life they imply, we are saved by the institution of the State, which comes into existence at the promptings of our morality, and which continues in existence to secure the free exercise, by its individual members, of their common moral rights, irrespective of their own power, or want of power, to maintain them. The extent, therefore, of the realized freedom of the individual members of a community is measured by the extent to which the rights that it implies are recognized and sanctioned by the State of which they are members.

But rights are of two kinds and are concerned with two different aspects of life. By the one the personal relations of the individual with the other members of his community, by the other his relations with the State, are determined. As regards the former, the socalled civil rights of person and property, all the States of Europe stand practically on the same level. Against selfish impulses, passions, and interests ; against wayward- 
ness and caprice; against individual power and might, these rights and the freedom they imply are equally secured to all the peoples of Europe, and secured in accordance with the same general rules or laws of conduct. This sphere of life has been, once for all, brought within the realm of freedom; and that it has been so we owe to Rome. This is the abiding obligation of mankind to her. But within the other sphere, the sphere of political right, the right of the individual to a share in moulding and guiding the life of the community of which he is a member, the condition of things is very different. In no two States of Europe has this right been realized to the same extent. In some-as, for example, in Russia-the first beginnings of a recognition of it date from quite recent years. In several, as in Russia, Germany, and Austro-Hungary, the right is so restricted by the privileges and prerogatives of the Sovereigns of the States as to be more of a sham than a reality; while in all its recognition is only a more or less imperfect approach to its 82 
full realization. But each State has to win it for itself in accordance with its own internal conditions; and it is on this fact that the final sanction and justification of its claim of freedom and independence rest.

It is worth while to try to understand why private personal rights should have obtained so full and universal a recognition, while political rights should have so lagged behind and have been so unequally recognized. It will help us if we look, in the first instance, at Rome. In her history we see a movement the very reverse of what has taken place in the history of Europe. Under the later Republic her citizens enjoyed equal political rights; but rights based upon a morality as local and exclusive in its nature as the morality of a Greek city. Neither the rights nor the morality from which they sprang could, from their very nature, be so extended as to embrace a population as numerous as that of some even of the smallest of our modern communities. 'They implied in their actual working a population not larger than could 
be brought together to discuss the common interests in a single meeting-place. The chapter in the history of Rome which would deal with the causes of the gradual disappearance of the political rights which the citizen of Rome itself enjoyed under the Republic, and the equally gradual and almost simultaneous realization and subsequent retention of his full civil rights, not simply as a citizen of Rome, but as the despotically governed subject of an Empire holding under its dominion the whole known world, is a chapter that has still to be written. I can refer here only to points in it.

The citizen of Rome did not distinguish, as we do, between law and morality. It was not an inward individual conviction of what was right and what was wrong that determined his conduct in life. It was simply the inherited laws and customs of his city. He never even conceived of a moral influence which would exercise its sway over men irrespective of any coercive power behind it; and irrespective, therefore, of differences of law and custom 84 
and institution. But the struggle between Patricians and Plebeians gradually led to the recognition of an absolute equality of individual right in the eye of the law. This was the final outcome of the movement of life within the city proper. But it was not accompanied by any change of moral disposition or spirit. It was still the coercive power of the law, as maintained by the State, that lay behind, and that was the sole sanction of the right. This bare abstract individual right, associated with the only outward thing with which such a right can be associated, the acquisition and possession of property, became extended, under the Empire, till it included within its scope and operation all its subjects without distinction of locality or race, or rank or condition of life. The mutability of man's life, within this sphere of it, was balanced and corrected by a fixed principle, universal in its nature and equal in its application to all. But within a life of which this was the highest expression there was no room for politics; and there were none. Below the Emperor all were equal; but over all he 85 
was absolutely supreme. In a far more unquestioned and unquestionable sense than any modern sovereign, the most despotic, the Emperor of Rome could say of himself that he was the State. In the Empire there was no idea of a life of which personal rights formed merely a part, and towards the fuller attainment of which they were merely instrumental. The power of the Emperor was accepted and submitted to as the power of an inexorable fate, from which there was no known way of escape. That there was a restlessness of spirit under this condition of things, a profound discontent with the narrow, rigid character of life, all the literature of the Empire, peculiarly Roman in its origin, makes abundantly evident. But there is in it no indication of a new way of life, in the pursuit of which men could again combine in active political co-operation. It was not from Rome that this new way of life was to come.

We are too apt to look on the decline and fall of the Roman Empire as if it were due simply to extraneous circumstances. The causes of it were in reality inherent 
in itself. The political progressive life of the community under the Republic had broken up under the Empire into its component atoms, and to each atom of the old body was ascribed an abstract personal private right. There was no living moral principle, uniting in its aim subject with subject, or subject with Emperor. The Emperor domineered, and the subject submitted. Even, therefore, if the barbarian invasions had never taken place, one of two things must have happened. Either the Empire must have broken up from within, and the separate fragments have continued to exist for a time, till they also broke up, and till, at last, they must all have disappeared as completely and as irrevocably as the Persian Empire and its component parts have done. Or it must have continued to exist with a life as stationary and unvarying in all its relations and conditions as has been the life of the Chinese Empire. From both of these alternatives Europe has been saved by Christianity. It was not, however, saved by the bare acceptance of the truths of 
that religion, as summed up in a series of dogmas. That kind of acceptance it found under the Empire, as it finds it, even down to our own day, in much of the teaching of the Churches, and in their whole attitude towards the secular life. The Empire became nominally Christian. But it never attempted to apply the teaching of Christ, as giving a rule of conduct, in accordance with which man's life on earth was to be renewed and reconstructed. What the life of the Empire was before the acceptance of Christianity it remained after. The Emperor still continued to possess a power in what then, for the first time in the history of the world, began to be called the secular relations of life, as absolute and irresponsible as any of his predecessors; and his subjects still continued to yield this power to him with as little question about its sanctions and validity. The Empire had to fall, if Christianity was not to remain a mere abstraction, a thing in the air, without any bearing on the relations of our life with one another; and the fall 88 
was brought about by the invasions of the barbarians.

Then followed a period of from two to three hundred years during which Europe was in a state of chaos. Except within the Church, there was neither fixed order nor regular discipline anywhere to be seen. Gradually, however, and under the influence of the Church, a new order of things began to show itself. Looking back on that period of European history, everything seemed to point to the establishment of a theocracy, co-extensive with the Church, and within which all political power would have been exercised by a sacerdotal caste. Whether this would have been consistent with human freedom, as we now know and think of it, is not open to question. Whether it would have been consistent with a full acceptance of Christianity and a full application of its principles to politics has been ever since a subject of dispute. But with the founding of the Empire of Charlemagne there came into existence, for the first time in the history of Europe, a power which claimed for what it did an 
EUROPEAN INTERNATIONAL RELATIONS

authority and sanction of its own, not derived directly from, nor dependent upon, the Church. The controversy between Church and State to which this claim led has gone on through the centuries. It culminated, but did not end, in the Reformation. Even the Reformed Churches, though in most cases they accepted a temporal ruler as their nominal chief, still continued to claim a special sanctity for themselves, which they denied to the institutions of the so-called temporal power. As time has gone on, however, this claim, as made both by the Roman Church and by the Reformed Churches, has met with a steadily decreasing respect. More and more, men have been realizing that Church and State are not, or ought not to be, antagonistic the one to the other, and that the purpose of both must be the same. Both are in truth merely instrumental to the divine purpose on this earth, for the unfolding of which men, as sons of God and brothers of Christ, are made directly and immediately responsible, a purpose allembracing in its scope, to the progressive 90 
manifestation of which each generation of men makes its own contribution, and by sharing in which every man in every generation becomes a sharer in an all-embracing life.

The Reformation is generally represented as having sprung from the corruptions of the Church; and these were, in fact, its prevailing influence. But it has been too often forgotten that the corruptions themselves resulted from the attempted isolation of the life of the individual members of the ecclesiastical hierarchy from the life of their fellows outside it. Isolation, even when it is corporate in its character, does not bring us nearer to Christ or to $\mathrm{His}$ kingdom, but only serves to make the individual the creature of a narrow, unyielding rule of life, or throws him back on the unregulated impulses of his own selfish passions and interests.

It was with the Reformation that the claim of the individual to the exercise of political rights first emerged as a real factor in the lives of the peoples of Western and Central Europe. Before then, how- 
ever, private personal rights had obtained a large and general recognition. Sovereigns had nothing to lose by opposing them. These rights might everywhere prevail, as between individual subjects, without diminishing the power of the sovereign over the subjects as a whole. But the claim of the subject himself to a share in the exercise of the sovereign power was of a very different kind of importance. To yield this would be to consent to put a limit to his own power; and no sovereign has ever given that consent, except through fear of the consequences of a continued refusal of it. The history of the various peoples of modern Europe has turned upon the struggle between the actual possessors of political power and the claimants to it; and associated with it, and prompted by it, as its necessary pre-requisite and safeguard, there was the struggle for national independence. But the movement was not simultaneous throughout Europe. It showed itself first in England; and it was here that it achieved its first great and abiding triumphs. On the Continent it 
can hardly be said to have made much headway till after the conclusion of the Napoleonic wars. There was still too much of that original confusion of peoples and languages out of which European life has been gradually emerging into definite shapes and forms, to allow it to make any steady, settled progress. The history of last century did much to clear away this confusion. But it still continues in Central, Eastern, and South-Eastern Europe; and it is from these areas that all our troubles since the middle of last century have come, and will continue to come till those distinctions between peoples and languages, essential to the development of a free political life, have been recognized and secured. 


\section{VII}

So much for the first of the two aspects which the subject of the freedom and independence of the separate European nationalities presents for our consideration. In their religion, in their education, in the spirit of their laws, in the conception of freedom which has been the guiding and moulding influence of their life; in all these there is no evidence to justify the view that their differences are of such a kind as to imply hostility towards each other. On the contrary, all the evidence, so far, points to a real community of life between them. How, then, does the claim of each to the possession of an absolutely supreme irresponsible sovereign power, a power not subject to any other power on earth, affect the question of their relations? Let us look at this claim, first, as it concerns the domestic life of each.

The legal theory of sovereign power is 94 
that in every independent political society there must be a determinate person, or determinate body of persons, to whom or to which is entrusted the power of making laws for the regulation of the life of the society and of enforcing obedience to them. The generality of the society must be in the habit of obeying the common superior, otherwise there could be no society. On the other hand, the common superior, whether determinate person or determinate body of persons, must not be subject to any other constituted earthly authority, otherwise there could be no freedom or independence. This is the legal theory, and from a strictly legal point of view it is justified by the facts. In every independent political society there must be a recognized source of law, a habit of obedience to the law on the part of the general body of the members of the society, and a power of enforcing obedience where the law is transgressed. This is what humanly enacted and operative law must mean. Nevertheless, there nowhere actually exists, whether 
constituted or unconstituted, determinate or indeterminate, an absolutely supreme irresponsible sovereign power. And by this it is not meant that in every exercise of human power there is an implied moral responsibility. For this is an inward check on the exercise of power which too readily yields to temptation in every one of us to be relied upon as an actually effective check. What is meant is that no human power can be stretched to its recognized legal limits, much more to limits that have not even the appearance of legal sanction, without some fear of injurious consequences to itself, and, where this fear is not strong enough to prevail as a check, without sooner or later actually incurring injurious consequences.

In our own country, for example, the determinate body of persons, who at any given time compose the Parliament of the United Kingdom, is legally possessed of a supreme sovereign power to do exactly as it pleases, and to enforce obedience to what it actually does please it to do. It has the legal power to continue indefinitely its own 96 
existence, and no other constituted power on earth can question its right to the exercise of this power. It has the legal power to confiscate the property of religious bodies of every denomination, to close their places of worship, and to forbid the teaching of religion throughout the land. It has the power to close every school in the land. It has the legal power to impose taxation up to twenty shillings in the pound on all incomes. There is, in short, no legal limit to what it can do. It is theoretically unfettered in the supreme sovereignty of its power. In reality, however, its power is not of this kind at all, nor does it exercise it in this spirit. 'There may indeed be, and there no doubt are, times when, under the influence of party spirit, it stretches its power beyond its just limits; but on the whole and in the long run it recognizes that it is of the nature of a trust which it holds from and for the community at large, and that its real operative effect depends upon the consent of the community which it represents and for which it acts. 
EUROPEAN INTERNATIONAL RELATIONS

We are not primarily governed by Parliament or its laws. If we were, the spring and purpose of our life, all its ruling moral and spiritual influences, would be totally different from what they actually are. Unless the sovereign principle of a free, independent, ordered life operates in each one of us, it cannot operate in that determinate body of persons who at any given time compose our Parliament. Our reason tells us that it must be so. On the other hand, however, we could not, each by his own unaided reason, determine, or each by his own unaided physical power, secure, the conditions of a free, ordered, independent life. For this we require Parliament, and Parliament supported in its decisions by all the power which, joined together and acting as a community, we can give to it. How else can we justify or explain the unlimited demands, extending even to the giving up of life itself, which Parliament may make upon us, and which, at any rate in times of supreme crisis, when the foundations of our life are exposed to the risks of destruction, we willingly yield to it? The 98 
final sanction of these demands must be the moral requirements of the life of the individual. There is no sacrifice which he ought to shrink from making in order that he may retain the conditions of a free life. His freedom is what he himself is, and hopes to become, and without it he is nothing. The State is merely his instrument. Those in whose hands its power for the moment rests measure the needs of our common life, and make the demand upon us for the sacrifices that correspond to them; and the demand may be for the last and highest sacrifice of all. The sovereign power of a free and independent State derives, therefore, all its final and abiding sanctions from that sovereign power, in each one of us, in accordance with whose spirit and dictates we work out the purpose of our lives.

This is the case of a freely constituted well-ordered State. It is different in a despotically governed country, though even here there is no absolutely supreme irresponsible power. A pure despotism necessarily implies a stationary unprogressive life on the part of those subject to it. It is 
impossible to conceive of a people conscious of a growing and expanding life, a life animated by the desire for better conditions than it actually possesses, ever consenting to submit this life to the arbitrary will of a single member of its community. But even where the life is stationary, and this consent is tacitly given, the power of the despot operates only within limits. He has to regulate the exercise of his power in accordance with the established usages of the people over whom he rules: he has either to do this or to run the risk of assassination or revolution. There is nowhere on earth such a thing as an absolutely supreme irresponsible human power. However large may be the extent of the sphere left open to the exercise of caprice and arbitrariness, everywhere that exercise has to submit itself to some at least of the conditions of our common humanity.

But if this is true, if it is true that the claim of each European nation to be free and independent is, so far as its strictly domestic life is concerned, the same in principle and substance as the claim of I00 
each individual member of the nation to be free and independent, if the State is merely instrumental to the provision and maintenance of the conditions necessary to the free and unhindered exercise of their powers by its individual subjects, and in accordance with a spirit and purpose common to them all, how does the question stand in regard to the relations between the nations? Is the freedom and independence of one nation inconsistent with or inimical to the freedom and independence of its neighbours? On general grounds, as we have seen, on grounds of community of religion, of morality, of education, of the principles of civil polity, of community in those aims and purposes on which a free, conscious, ordered life for all must rest, we should answer this question with an unhesitating negative. But this is not enough. For the answer, even though it may be true, carries with it neither conviction as to its truth nor guidance as to how it is to be made effective, so long as we are faced with the fact that every nation in Europe acts as if it were false. 
EUROPEAN INTERNATIONAL RELATIONS

-These nations all arm themselves against each other; and towards the maintenance of their armaments they all divert a large proportion of their resources, both material and intellectual. They do this, moreover, on the supposition that their several interests are in reality opposed. In our own time, however, this supposition has not been allowed to pass current without serious question; and, during at least the last fifteen years, every Government in Europe, when it proposed to make additions to its armaments, has accompanied the proposal with an apology for it both to its own subjects and to the world. It was not, it said, that it was influenced by any hostile aggressive intentions against itsneighbours, but that it feared hostile aggression from them. Its own interest was peace, and it armed itself solely in order that it might maintain peace. Not to be prepared for war, and prepared to the utmost extent of its resources, was to make war certain. This was the apology made not by one Government only, but by every Government in turn. But it could not have been 
sincerely made by them all. It must obviously have been made by one or more of them in order to counteract a growing conviction among the several peoples of Europe that their real interests were not inimical to each other, but were the interests of a common peace, and to counteract it in the interests of aggression and war. Obeisance to peace had to be made by all; but if by all it had been made honestly and sincerely, we should not now be in the midst of an unspeakably barbarous and cruel war.

If we look back on the history of Europe, and try to get from it an answer to our question, the first thing we have to notice is that the right of nationalities to a free and independent life has obtained in our civilization a respect and recognition it never obtained in any of the older civilizations of the world. It was a right never acknowledged by the Romans. The spirit of their civilization was national and exclusive. They recognized no community of life between themselves and their neighbours identified with the continued independent 
existence of each. It never even entered into their thought to recognize it, as their whole career of conquest made abundantly evident. And it was as foreign to the Greeks and to the Oriental peoples as to them. In the conflict of the moment we are too ready to overlook this characteristic of European life. We seem to see nothing but the spirit of war operating between nations; and the fact that we submit to its waste and cruelty seems to be the denial, given by some power beyond our control, of the possibility of our ever overcoming this spirit by the spirit of peace and reconciliation. But this is to fail to see the facts as they are. It must never be forgotten that the life of Europe sprang from a condition of things in which the arbitrary individual will was allowed to run riot without formal authoritative check or restraint of any kind; and that its effort since then has been to bring order and freedom out of this original chaos and confusion. In pursuing this object it was essential that peoples should mark themselves off from each other. There was no 
possibility of Europe being organized as a whole in accordance with either religious or political freedom. Differences of speech and conditions forbade it. On the other hand, the idea that there was a community of interest underlying their differences has never at any time been without a large influence on their affairs.

There is a European life and civilization, and a history of it, without a knowledge of which it is impossible to understand the life or the history of the several peoples that have contributed to it-a life and civilization wider and larger than the life of any single European people. All the great movements which have affected the life of each have affected, though in varying degrees, the life of all. The feudal system was not limited to one country. It extended to all. All shared in the dissatisfaction with existing spiritual conditions which led to the Crusades. The revival of learning in the fifteenth century and the Reformation of religion in the sixteenth were not the fruits of the life of one people. Nor were the strictly political movements 105 
in the life of each merely local or national either in their origin or influence. In spite of the great variety of political organization that prevails among the peoples of modern Europe, it is still true to say that the internal history of each is to be explained only in the light of an endeavour common to them all to realize the same ideas of political right. There is a life of Europe which no single people in it can completely realize by itself, a life which draws all its great inspiring and constructive principles, not from those things which are peculiar to each, not from distinctions of race, nor from extent of territory, or of population, or of wealth, or of power, but from the realms of intellect and spirit, in which they have all a common and abiding interest.

The movement in Europe by which nations have come more and more to distinguish themselves from each other and to form independent States, though it began after the downfall of the Charlemagne Empire, and continued in an uncertain, fluctuating way all through the Middle Ages, became clearly marked and conscious 
of its own purpose only after the Reformation. It suffered a temporary eclipse under Napoleon, but only to emerge again after his downfall with renewed vigour; and before the close of last century it had, except in Central and Eastern Europe, practically accomplished its object. It is, or it ought to be, one of the great issues of the present war to provide for its accomplishment also within this area.

But to see in this movement merely a progress towards the separate organization of their own life on the part of the different peoples is entirely to misread the inner meaning of the history of Europe. It is what lies on its surface, but it is not what is, or is to be, its highest outcome. As it proceeded, as the idea of nationality obtained an increasing respect and recognition, it brought into existence with it a sense of community of interest between the nations which has deepened with every step in its advance. In this regard there is a striking analogy between the development of life within the self-governing portions of the British Empire and the 
development of European life. As the sense of community of interest between the several constituent parts of this Empire has deepened, as the bond which unites them has strengthened, in proportion as their local independence and freedom has been recognized and respected, so it has been, under far more complex conditions and with a much more protracted history, in the case of the peoples of Europe. In this case, the idea of a community of interest dates from the seventeenth century, for that century saw the birth of international law, of the system of European diplomatic relations, and of the idea of a European balance of power. These all assumed a community of interest between the nations, and their purpose was to maintain peace by regulating their relations in accordance with this interest. To say of them that they have been ineffective for their purpose is to say what is no doubt true; but to say this and nothing more is wholly to miss their real significance, and to deprive ourselves of the guidance that is to be got from our past history Io8 
EUROPEAN INTERNATIONAL RELATIONS

when we come to deal, after this war is over, with the means by which a similar catastrophe is to be prevented in the future. They have been ineffective in the past, not because what they aimed at was impossible of attainment, but because the historical movement, out of which they sprang, was still incomplete, because there were large areas of Europe within which powerful dynastic interests hostile to them still prevailed. They all imply a connected system of European States, a completed commonwealth of nations. Unless they do imply this they are meaningless; and till what they imply is actually realized they must remain ineffective for their purpose. 


\section{VIII}

INTERnAtional law is devised for the purpose of performing the same part in regulating the relations of nations that the civil law of each nation performs in regulating the personal relations of its individual members. It is not its function to interfere with the right of each nation to manage its own affairs, unless what the nation proposes to do infringes on the enjoyment of the same right by other nations. It rests upon and is an application of the same principles and rules of conduct as are embodied in the domestic law of every nation in Europe; and these principles and rules are no more alien to the character and purpose of the nation's life in the one set of relations than they are in the other. International law is intended to be instrumental to securing for each nation the conditions of its own 
freedom and independence; and to secure these conditions by a sanction which no nation could provide for by its own unaided efforts in isolation from the others. Isolation must mean here, as in every other sphere of moral conduct, the subjection of the weak to the arbitrary will and power of the strong. Every page in the history of Europe illustrates this ; and in no page is it illustrated with such consequences as in that which is now being written.

It ought further to be noted that international law does not concern itself with what nations may make of their life in the future, nor with what Europe as a whole may make of its life in a possible future development of its common interests. It is merely declaratory of existing, recognized, and established national rights, and of the corresponding duties implied by them. It does not, therefore, require a European Parliament to frame it. If it did, the task which would lie before Europe after the war is over would be hopelessly difficult. It has been the creation of jurists, just as the Roman Civil Law was the crea- 
EUROPEAN INTERNATIONAL RELATIONS

tion of jurists; and it is in the hands of jurists that it ought to be left.

This view of the scope and purpose of international law is supported and confirmed by the European system of diplomatic relations which came into existence with it. This system rests on an application of the law of civil vicinity to the vicinage of Europe as a whole. By that law no man is complete master of his own actions even on his own ground. $\mathrm{He}$ cannot do with his own just what he pleases, if what he pleases to do injures or threatens to injure the interests or the life of his neighbours. They have a right to appeal to the civil tribunals to prevent any new use of his property which is, or which threatens to be, detrimental to them; and the judge, even before it is clearly known whether the innovation is damageable or not, is competent to issue a prohibition until the point is determined. It is of importance to note that it is against his liberty to make a new use of his property detrimental to his neighbours that the law provides. 
Our system of diplomacy rests upon the assumption that the principle of this law is as applicable to nations as to individuals. In accordance with that system every nation in Europe has the right to know, and it has imposed upon it the duty to protest against, any innovation by another nation that either actually is, or that threatens to be, detrimental to its own existing recognized rights and liberties. Our diplomacy assumes a settled condition of relations between States, and it seeks to prevent the occurrence of anything that would upset this settled state of things. Every State in Europe acknowledges this and acts upon it. Every State has in its capital city authorized representatives of every other State, whose places of residence in that city are supposed to be part and parcel of the territories of the States they severally represent. It is the recognized duty of each of these representatives to watch over the existing interests of his own country, and to report to his own Government upon any action or proposed action taken or to be taken by the 
Government to which he is accredited, if he thinks this action may be prejudicial to these interests. If so instructed by his own Government, it is his recognized right and duty to protest against the action, and, if possible, to prevent it by negotiation. But when negotiation fails, there is no recognized tribunal to which the question in dispute can be referred for peaceful adjudication and settlement, even though the question is one of law, to be determined by actually existing and mutually acknowledged rights and liberties. Here, therefore, the analogy between the application of the law of neighbourhood to individuals and to nations ceases.

What the constituted judicial tribunal has been to individuals in the settlement of disputes springing from the interests of neighbourhood, that the balance of power has hitherto been to the nations of modern Europe. The disputes in both cases are, and are recognized to be, of the same nature; and up to a certain point the process of settlement is of the same kind. They are of the nature of civil suits in 
which both parties claim to be possessors of a right derived from a law whose authority is acknowledged by both. When negotiation fails to settle the dispute, individuals resort to a tribunal appointed to adjudicate upon the facts and the law. If the judgment of the tribunal is accepted by both parties, the dispute is settled by it. But if one of the parties refuses to accept it, and "takes the law into his own hands," the force of the executive authority that lies behind the tribunal is then resorted to and obedience is imposed upon him. On the other hand, when negotiation fails to settle a dispute between nations, there being no constituted judge to refer to, each at once takes the law into its own hands, and appeals to the arbitrament of war.

It may be said that this is stretching the analogy between the suits of individuals and the suits of nations farther than the facts justify ; and that nations have often forced war on their neighbours in the spirit of beasts of prey and without a shadow of a claim of right, human or divine, to support them. 'This is no doubt true. But it has been 
true also of individuals. Without, however, pressing this point, there are two facts of our modern history, consideration of which will make us pause before we reject the view that the actions of nations in their relations with each other are influenced by the rights of vicinage, and that the final judgment of the vicinage itself on these actions is determined by the acknowledged existence of these rights.

The first is that no nation of modern Europe has entered into war without asserting that the war has been forced upon it by the actual or threatened infringement of its rights and liberties by the enemy nation. But it does not make this assertion simply to satisfy its own conscience. If that were all, there would be no call to make the assertion. It makes it, and makes it all the more loudly, even if what leads it into war is not the need to maintain its own rights, but the vulgar commonplace desire to aggrandize itself at the cost of its neighbours. It seeks, or by underhand methods strives to make, plausible reasons to justify its action. But, again, it does this not I 6 
in order to reconcile itself to what it proposes to do. 'That is not a source of trouble to it. It has in mind the judgment of its neighbours; and one of its first concerns is to prepare a case to lay before them upon the merits of which it hopes to influence that judgment in its favour and to obtain such moral or material support as might result from it. How is it possible to explain this, except on the supposition that it is making to them an appeal, in its own justification, to a principle of right of which it is not the sole exclusive possessor, but which it shares with them, and of which it and they are the common guardians and upholders? It denies that it is an aggressor. It takes the law into its own hands, but it claims that in doing this it is acting not merely in its own interests, but in the interests also of surrounding nations.

The other fact is the existence of the balance of power. Much has been said and written against this balance, as if it were primarily an instrument of war and not of peace. But to assert this is to 
misunderstand its historical significance. It is not of the same nature as a secret alliance between two or more nations, which is invariably entered into for some sinister aggressive purpose which could not be proclaimed to the world. Its purpose was known, if not openly avowed. It came into existence to check the prevalence of arbitrary power, and to check it in the interest of the independence of nations ; and on the whole it has accomplished its purpose, though at an incalculable cost to the nations. It has operated to its full extent only in periods of supreme crisis, when obviously the rights and liberties of the nations were exposed to imminent danger of being destroyed. One such crisis Europe had to face rather more than a hundred years ago. It is now in the middle of another. But it is to be noted that though the danger always springs from the same cause, it does not spring from the same quarter. If it did, there would be reason in the contention that the balance of power was a mere instrument of war, instead of II 8 
being, what it virtually is, an instrument for checking and punishing aggressive power. By it the nations of Europe have been divided into two opposing camps; and we are apt to see in it nothing more than this. But the divisions have not been fixed and invariable. They have shifted with the shiftings of power; and it is impossible to give a reasoned historical explanation of these shiftings, except on the ground that they took place in order to safeguard the peaceful development of the life of the nations as a whole.

In the Napoleonic wars we sided with the main body of the States of Europe not in order to aggrandize them or ourselves at the cost of France, but to make manifest to the people of that country that they could not embark on a policy of spoliation and aggrandizement at the cost of their neighbours without having to reckon with Europe as a whole. In the result the principle of the freedom and independence of nations successfully asserted itself. France was forced back within the community of nations and made 
to realize that her arbitrary will and power must be subjected to conditions consistent with the life of that community. After the conclusion of these wars the balance of power remained for long in practical abeyance. The nations turned themselves to the repair of the wastes of war, and their attention was mainly absorbed in the development of their domestic life. Such wars as took place were entered into by subject nationalities to secure their freedom and independence; or, where this was not the case, they were regarded rather as episodes in the life of individual nations than as affecting the life of Europe as a whole. During this period Prussia pursued a not too obtrusive policy of aggrandizement. She watched her opportunities, and after her war with France she emerged as the head of the German Empire and as the most powerful military State in Europedetermined, moreover, to use her power in furtherance of a continued policy of aggrandizement. She was relatively late in coming into possession of her power; but that did not, in her view, invalidate 
the justice of her claim to do what others, as she asserted, had done before herreconstruct the world in accordance with her own will, as measured by her power to assert it.

In face of this claim, which she made with a gradually increasing boldness and insistence, the principle of the balance of power once again came into operation; and once again Europe is plunged into war in defence of the rights and liberties of nations. But though the immediate issues of the war are the same as they were a hundred years ago, the nations that are in the two scales of the balance are not the same. The danger to the common interests of European peoples does not come from the same quarter. Then we fought with Germany and Russia against France. Now we are fighting with France and Russia against Germany. Then France was forced back within the limits of the existing State system of Europe. Now, unless we are to prove ourselves false to the whole history of Europe, unless we are to give up the slowly acquired and still 
imperfectly recognized common rights of the nations to the free and independent development of their domestic life, unless we are to be false to those principles of life which we have inherited from our fathers, and false to our duty to maintain them for ourselves and for others and to hand them on unimpaired to those who come after us, Germany must be taught that her unchecked and unregulated will cannot be the rule of her conduct in her relations with her neighbours; and she, too, must be forced back within the limits of the European State system.

But when this is accomplished there will still remain the task of estimating the permanent lessons of the war and of giving practical effect to them. Europe cannot emerge from the war to take up the lines of her life just where she dropped them when she entered into it. The barbarous waste and cruelty of war, the sacrifice of the private affections of life to it, the wanton breach of all the great guiding and restraining principles of human conduct which it involves, have never pene- 
trated so deeply into the hearts and minds of men as they have done in the present war. To lose its lessons, to fail to take advantage of them in order to establish the relations of nations on a foundation more consistent with the spirit of their common and advancing civilization, would be a monstrous and unspeakable crime against that spirit.

In considering these lessons and their possible practical effects on the conditions of our life, we are not left entirely to the guidance of our own unaided reason. Men never are so left when they seek honestly and earnestly for a solution of the difficulties of life. We have inherited from the past history of Europe certain clear and indubitable indications of the lines of our future advance. As we have seen, there has been in that history a slow movement towards the disintegration of the originally amorphous population of Europe into its distinct parts, a movement everywhere influenced by the same spirit and the same aims, and everywhere conditioned by the requirements of a free, conscious, self- 
EUROPEAN INTERNATIONAL RELATIONS

governing life. It originated in a state of confusion and war throughout the length and breadth of Europe, and through all its stages it has hitherto been accompanied by war. But as it has advanced, as its purpose has become more and more clearly realized, the wars have altered in their character and aims. They have become less and less purely dynastic, and more and more associated with the determination of peoples as a whole to secure and maintain the conditions of a free life against the encroachments of arbitrary will and power. 'They have been more and more associated with the principle of nationality, and they have more and more clearly resulted in respect for it. The policy of our own country has been for long firmly grounded on respect for this principle. During last century it became the guiding principle of the policy of all the Western peoples of Europe. But it has not yet obtained acceptance or recognition in Central or Eastern Europe. As might have been expected, it was from this region that 
most of the European troubles of last century sprang: and it was in this region that the present war had its origin. The first task of European statesmanship, after the war is over, ought, therefore, to be the settlement of the life of the peoples within this region in accordance with principles that are already in operation in other parts of Europe; and this has been already publicly proclaimed both by Mr. Asquith and Sir Edward Grey as one of the great issues of the war.

But the movement towards the separate organization of the life of the various peoples of Europe was accompanied by another movement not less significant, though less obvious, in its character. As the line of demarcation between them became more clearly drawn, they began to define their relations towards each other as independent sovereign powers, and to define them in the interests of peace. The principle of definition was respect for their severally existing and acknowledged rights and liberties. It was a principle essentially conservative in its character and purpose; and unless it had 
been so it could not have been used in the interests of peace. In its operation it sought simply to preserve the conditions under which each people might develop its own life in peace and security; and it implied that they all had a common interest in the maintenance of these conditions.

The principle is embodied in our so-called international laws. But these laws have hitherto lacked three of the essential conditions of all law, properly so called.

In the first place, they are not the enactments of a body of men constituted with the consent of all the nations to frame them, unless we can regard the Hague Conventions as being such enactments. I have already expressed my own opinion that the task of framing them ought to be entrusted not to a body of statesmen but to a body of jurists. It has, indeed, been suggested that what is needed in order to work out and reconcile the common interests of the peoples of Europe is a European Parliament. I will not attempt to penetrate into what may happen in a still clouded and I26 
remote future; but I am confident that the problems which lie immediately in front of us are not of such a nature as to permit of their being usefully submitted to, or fruitfully considered by, such a Parliament. It would be a modern Babel, marked not only by a confusion of tongues, but by a total absence of any common ground-plan of the structure by which we were to reach our heaven. These things we have to recognize and accept. The right to initiate, and to carry on, further advances in our civilization must still be left to the several peoples acting in accordance with their own special conditions and their own sense of responsibility for them. What they can in common do is to embody in a legal code that scheme of relative and co-operative rights and liberties which their continued independent existence as States actually implies and involves; and this, I repeat, is a task for jurists, guided in performing it by the general principles of that civil polity which prevails throughout the length and breadth of Europe, and is not a task for legislators in the ordinary sense of that term. It 
EUROPEAN INTERNATIONAL RELATIONS

might, however, add to the binding and operative effect of the code if, after it was framed, it were submitted to the legislatures of Europe for their several sanction and approval.

The second defect of our existing international laws is that they do not provide for any constituted tribunal to adjudicate upon them. Each State has been its own judge of its rights and liberties of action under them. We have seen that the parties to an international dispute appeal on the merits of their respective causes to the judgment of their common vicinage; but they do this only after a verdict has been already pronounced by one or both of them, and after resort has been had to armed force to support the verdict. This is, to all intents and purposes, to abrogate the law and to make it of no effect. If there are to be international laws, if the spirit of peace and justice, which is at once the source and end of all law, is ever to prevail between nations, then this is a defect which must be remedied. The right of States to be judges in their own cause ought no 
longer to be recognized; and the appeal to the judgment of the vicinage ought to be made part and parcel of the law. All the States, as a matter of fact, acknowledge the existence of international laws. They all recognize that their relations with each other come within the realm of acknowledged and justiciable right. How then can they consistently continue to claim a right hostile to the acknowledged 'parent right, and totally inconsistent with its real operative effect? To continue to claim this right is to relegate international laws to the region of childish and futile maxims of conduct which are set up to-day and to-morrow broken. It would be a sign not of an adherence to right, nor of a desire that it should prevail, but of the existence of secret, sinister designs and ambitions alien to it.

The third defect is consequential on the second. As there has been no constituted tribunal to which disputes between nations could be referred for judgment, so there has been no constituted executive power authorized to enforce judgment when en- 


\section{EUROPEAN INTERNATIONAL RELATIONS}

forcement might have been necessary. So long as States claimed and were universally recognized to be judges in their own cause, so long as they claimed and were allowed the right to take the law into their own hands and to enforce their own interpretation of it, no regularly constituted European executive power could have come into existence. The crude beginnings of it are, however, to be found in the balance of power. But it has hitherto operated without definite plan or method. In its very composition it has been unsteady and uncertain. None the less, its purpose was clear. It was a more or less formal league of those States which desired to safeguard and maintain the actually existing condition of State relations against those which were suspected of a design to make a burglarious breach in them. How it is to be converted from an uncertain, fluctuating balance into a steady, permanent concert of European Powers is by far the most difficult problem that now faces us. It does not appear rash to assume that the States of Europe may be brought at the 
conclusion of the war to consent to the drafting of an international code defining their relative rights and liberties as independent members of a common State system. Nor does it appear rash to assume that they may be brought to consent to the establishment of a regularly constituted tribunal, to which questions arising under this code may be referred for judgment. 'These things are not only the necessary foundations of permanent peaceful relations between them, but they also lie in the plain path of their common historical development. So too, indeed, does the idea of an executive Power authorized to enforce a European judgment on any State which, by taking the law into its own hands, declines to submit itself to this judgment. But the task of realizing it is of a very different kind from the others. If the direct and immediate responsibilities of all the States were purely European in their scope, it might be of the same kind. In this case their relative rights and responsibilities might be administered in a way completely analogous to the way in which their several 
EUROPEAN INTERNATIONAL RELATIONS

domestic rights and responsibilities are administered. They might in common maintain an armed European body of men, whose duty it would be to enforce, if necessary, the judgments of the European tribunal. But we have not arrived at a stage in the history either of Europe or of the world in which this would be practicable. All the greatest of the States, and some of the smallest of them, have extra-European responsibilities, which cannot be administered in common and which do impose upon them the duty and necessity of maintaining armed forces of their own not demanded either by their strictly domestic or by their strictly European requirements; and these forces might at any moment, and inevitably would, be thrown into the scales of a European quarrel. It would seem, therefore, as if we must still adhere to the idea of a balance of power. But it ought to be made to act with greater continuity and certainty of purpose ; and it might take the form of a permanent league of States bound together to sanction and support, with all their 
EUROPEAN INTERNATIONAL RELATIONS

power, the judgments of a European tribunal acting as the interpreter of a European law.

This may seem a lame and impotent conclusion to those who, deeply moved by the unspeakable horrors of the war, are rightly eager to see established some more certain and efficacious machinery for the maintenance of peace. But man's civilization does not advance by leaps and bounds. We have to win our way towards it by a slow, complicated, and difficult process. But if, as the result of the war, the nations of Europe can be brought to realize that there is a community of purpose underlying their historical development, a community of purpose identified with their several and relative rights as free, independent, self-governing States ; if they can be brought to define these rights in accordance with principles of law common to and acknowledged by them all ; and if, further, they can be brought to consent to the establishment of a duly constituted tribunal to adjudicate upon these rights, then, even without any authorized means of enforcing 
EUROPEAN INTERNATIONAL RELATIONS the judgments of the tribunal, a great step will have been taken towards a clearing of the issues between them, and towards the formation of a body of reasoned European opinion in favour of peace and against war ; and the war itself will not have been fought in vain. 


\section{IX}

I Propose, in conclusion, to try to summarize the argument of the preceding sections.

The idea of national freedom and independence, which has recently prevailed in Europe, assumes that each State has, or has a right to have, within itself all the requirements, moral and material, of a complete and self-sufficing life. To consent to be dependent for any of these requirements on its neighbours would be to consent to derogate, to the extent of the dependence, from its own unrestricted freedom of action, and to deny the absoluteness of its own sovereignty.

If this idea is accepted, there never can be any real community of interest between nations, nor any permanent peace. So long as two or more sovereign States exist there will be a struggle for supremacy between 
them, till at last one all-powerful State will subdue to itself all the other States of Europe, and ultimately also of the world.

The account which many, and these the most influential, of our political theorists have given of the meaning of the freedom and independence of the individual members of a single community has been in all respects analogous to this account of the freedom and independence of nations. It may throw light on the international problem to examine it.

These writers have assumed that the freedom and independence of the individual is something that belongs to him simply in virtue of his birth as a human being; something, therefore, that exists prior to the existence of his community, and which he brings with him into it. On this assumption the function of the State is to devise some scheme of things by which the several and conflicting claims of individuals shall be reconciled with as little injury to them as may be practically possible. The more of the individual and the less of the State that there is in the scheme, the better it is. 
The two must always be in opposition, and it is the individual interest which ought to predominate.

This theory of the origin and meaning of individual freedom and independence supports and confirms the prevailing theory of national freedom and independence. If it is a true theory, then the final sanction both for the existence of the State and for everything it does must be the sanction, not of freedom, but of a prevailing force. There is no other resting ground conceivable for it. In accordance with it, all the movement of life within the community can be nothing but an ever-renewed scuffle for the predominance of one section of its members over another; and all international movement must be of the same nature.

When, however, we look more closely at the facts of our life we find that the isolated individual, as the source and sanction of his own claims, is a fiction of the imagination. He nowhere actually exists, nor can he ever have existed, as the single, solitary possessor of those attributes that characterize human life and distinguish it from merely animal 
life. Everywhere, as a matter of fact, he realizes his life and learns to know what it means only in and through relations with his fellows acting in community one with the other. It is through the action and reaction of individual on individual in society that the purpose of human life is being gradually unfolded and made clear for us all. The purpose is individual. It exists, and can exist, only in the consciousness of each one of us, and it is in proportion to our will and our power to realize it that we are free. But though the purpose is individual it must be the same for all, otherwise there could be no community of interest in its realization. When we ask what it is, and in what form it finds definite expression, the only answer that can be given is an answer that refers us to the religion of the community. It cannot be found in a common desire to amass wealth, or to add indefinitely to the external possessions of life. These possessions never do and never can bring permanent satisfaction to the inner spiritual aspirations of men. They are in their 
proper place only when they are used as instruments for the building up of a life whose purpose lies altogether beyond them. Nor can the purpose be found in the pursuit of science, or of art, or of literature. These may and do help us to understand and to further it, but they neither separately nor together constitute it. Nor is it to be found in a common desire for freedom, for freedom has no meaning except as defined by reference to an end for the attainment of which it is an essential condition. The larger and the more all-embracing the end is, the larger and the more all-embracing is the freedom. The freedom of arbitrary will is one thing, the freedom of an ordered, regulated will is another. The one is the lowest form of human freedom, the other may be the highest. The freedom of the man who bends all his will to the attainment of wealth is one kind of freedom; while the freedom of the man who bends all his will to the attainment of an internal conscious spiritual harmony of life is another and very different kind. Among the peoples of the world freedom meant 
EUROPEAN INTERNATIONAL RELATIONS

one thing to the Jew, and another to the Greek, and still another to the Roman. It means for us something different from any of these; and the differences can be explained and accounted for only by reference to the different ends of life as these ends are defined in the different religions. There is no other area of life in which to look for their definite and concentrated expression. In our own case, in the case, that is, of the Christian religion, the end is a complete self-conscious personal and individual life. It is an end in which all men, without distinction of race or nationality or rank or occupation, are called upon to participate. It is the common birthright of all men as sons of a common Father, and heirs to His spirit. But it is an inheritance that has to be sought after and won. Though it never can be completely realized within the limits and conditions of time, it is still not a mere aspiration or abstraction, awaiting even the initial stages of its fulfilment in some future life. It is the inward source, the impelling spring, of all that is true and 
abiding in our life as we live it now on this earth; and till we see, in what we call our secular life, the gradual and progressive unfolding of its meaning, we do not see it in its spirit and truth, nor can we ever win, in time or eternity, to its freedom. It is by the transmutation of the relations and conditions of our life in accordance with it that we show that the spirit of Christ lives and operates in us.

This transmutation cannot, however, be made by the individual through his own unaided efforts. To effect it is the function of the State acting for the community as a whole. The freedom and independence of the State must, therefore, spring from the same source and have the same ultimate sanction as the freedom and independence of the individual. The one must be the instrument of the other.

At first sight, the legal theory of State sovereignty seems to conflict with this view. For according to it there is no power on earth that can call in question what the State commands. From the strictly legal point of view this is true. 
On the other hand, the sovereign power of the State is everywhere seen to partake of the nature of a trust exercised on behalf of the individual members of the community; and any breach of the terms or implied conditions of the trust exposes the State to the dangers of revolution. If in the life of the peoples of Europe as a whole there is an underlying community of purpose, there is nothing necessarily hostile to this purpose in the actual working of the sovereign independence of their several States.

Turning to the actual history of Europe, we find that it has hinged upon two ideas, the one inextricably associated with the other. They are the ideas of individual freedom and national independence. The movement towards their realization was not simultaneous throughout the length and breadth of Europe. It first showed itself among the Western peoples, and pre-eminently among the English. From them it gradually extended itself till, towards the close of last century, there was left only a relatively small area in Central and Eastern Europe within which its purpose was still unaccomplished. 
EUROPEAN INTERNATIONAL RELATIONS

Throughout all its stages it has been accompanied both by civil and by international warfare. It was inevitable that it should be so. But as it went on, as it gained in strength and coherence, as the political disintegration of the peoples became more and more clearly defined, so a new concentration of action and purpose began to show itself among them. 'This expressed itself in the body of European international law, in the system of European diplomatic relations, and in the balance of power. These all rested on the application of the principles of the law of civil vicinity to the vicinage of States within Europe as a whole. But no attempt has hitherto been made to give real operative effect to the principles. International laws have never been reduced to a code having behind it the formal consent and authority of the States as a whole. No European tribunal has been constituted to which disputes arising under the laws could be referred for judgment. Nor has any steady reliable means of enforcing obedience to judgment been devised. All these lie in the path 
of the historical development of European States; and they are the essential prerequisites of the maintenance of peace between them. To the joint drafting of an international code, or to the setting up of a tribunal to adjudicate upon it, no serious practical difficulties present themselves. But the devising of means by which obedience to the judgments of the tribunal might be enforced does present difficulties which, in the present stage of the world's history, it seems impossible satisfactorily to overcome. On the other hand, clearly to define what are the relative rights and liberties of neighbouring peoples possessing so many interests in common, and some of these of the most fundamental kind, as the several European peoples do; and to set up a tribunal to adjudicate upon them, even if there were no authorized means of enforcing the judgments of the tribunal, would be an enormous stride onwards in the regulation of European public opinion on international questions and a good augury of enduring peace. 

THIS BOOK IS DUE ON THE LAST DATE STAMPED BELOW

AN INITIAL FINE OF 25 CENTS WILL BE ASSESSED FOR FAILURE TO RETURN THIS BOOK ON THE DATE DUE. THE PENALTY DAY AND TO TO 50 CENTS ON THE FOURTH OVERDUE.

\section{JAM 231933

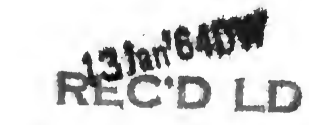 \\ $14^{\prime} 64-6 \mathrm{PM}$}


YB 21376

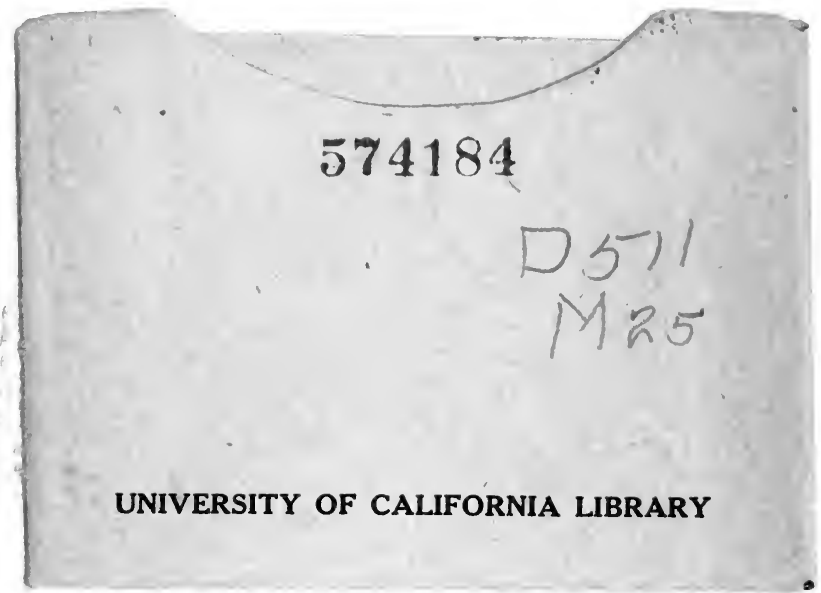


